\title{
Arid Site Water Balance: Evapotranspiration Modeling and Measurements
}
G. W. Gee
R. R. Kirkham

September 1984

Prepared for

the U.S. Department of Energy

National Low-Level Waste Program

under Contract DE-AC06-76RLO 1830

Pacific Northwest Laboratory

Operated for the U.S. Department of Energy

by Battelle Memorial Institute 


\title{
DISCLAIMER
}

This report was prepared as an account of work sponsored by an agency of the United States Government. Neither the United States Government nor any agency thereof, nor any of their employees, makes any warranty, express or implied, or assumes any legal liability or responsibility for the accuracy, completeness, or usefulness of any information, apparatus, product, or process disclosed, or represents that its use would not infringe privately owned rights. Reference herein to any specific commercial product, process, or service by trade name, trademark, manufacturer, or otherwise, does not necessarily constitute or imply its endorsement, recommendation, or favoring by the United States Government or any agency thereof. The views and opinions of authors expressed herein do not necessarily state or reflect those of the United States Government or any agency thereof.

\author{
PACIFIC NORTHWEST LABORATORY \\ operated by \\ BATTELLE \\ for the \\ UNITED STATES DEPARTMENT OF ENERGY \\ under Contract DE-AC06-76RLO 1830
}

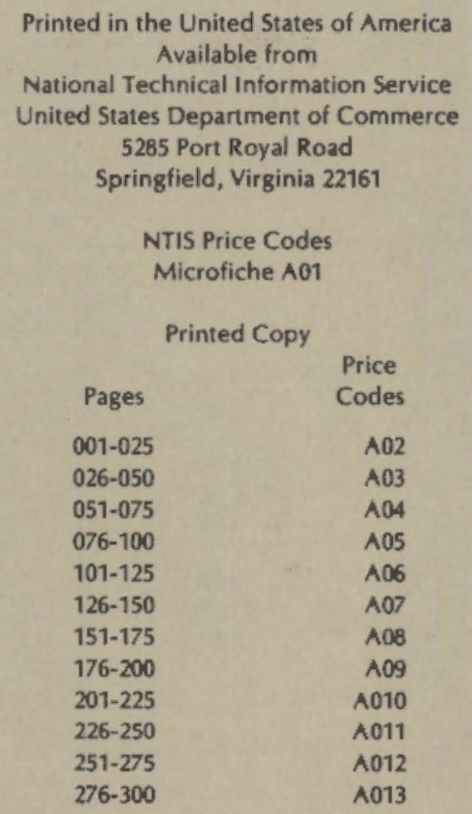


PNL -5177

UC-70

33679000465320

ARID SITE WATER BALANCE:

EVAPOTRANSP IRATION

MODELING AND MEASUREMENTS

G. W. Gee

R. R. Kirkham

September 1984

Prepared for

the U.S. Department of Energy

National Low-Level Waste Program

under Contract DE-ACD6-76RLO 183D

Pacific Northwest Laboratory

Richland, Washington 99352 


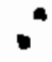

$\therefore$

$\bullet$

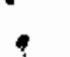

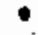




\section{ACKNOWLEDGMENTS}

We wish to thank our colleagues who have supported this effort in various ways: Kyle Ryan, for collection of neutron probe and other field data; Paula Heller, for measurement of the water retention characteristics: T. L. Jones, for his initial involvement in the project planning; and A. E. Reisenauer, for his support in the modeling effort. We also wish to thank Dr. G. S. Campbell of Washington State University for his helpful suggestions during the course of this work. 
$c$

$\therefore$

: 


\section{EXECUTIVE SUMMARY}

The National Low Level Waste Management Program (NLLWMP) of the Department of Energy (DOE) established the Transport Assessment--Arid Task at Pacific Northwest Laboratory ( $P N L$ ) in 1978. The primary focus of this task has been the assessment and development of modeling technology used to predict the transport of water and radionuclides through unsaturated sediment (i.e., unsaturated zone transport). Transport of materials through unsaturated soil is expected to be the dominant pathway for contaminant migration at most shallow land burial sites. To evaluate the magnitude of transport at an arid site, PNL conducted a field and modeling study to measure and predict water movement under vegetated and bare soil conditions.

We measured drainage in both bare and vegetated soil at a field location on the Department of Energy's Hanford site near Richland, Washington, during wet years (1983 and 1984). Both direct measurements of actual drainage and indirect measurements of changes in moisture profiles confirmed that water moves below the root zone and is lost to deep drainage during periods of low evapotranspiration. Measurements indicated that over $10 \mathrm{~cm}$ of drainage occurred during a 1-year period from bare sandy soil and over $5 \mathrm{~cm}$ of drainage from a grass-covered field site. It should be noted that these drainage vajues were specific to this field site because of soil and plant characteristics. While this amount may be representative for some portion of the Hanford site, it cannot be considered as a reference for the entire site, as other sitespecific characteristics could result in significantly greater or less drainage.

Water balance at this field site was also estimated using UNSAT-1D, a computer model that describes transient unsaturated flow in soils. Plant evapotranspiration was simulated using a time-dependent transpiration function for cheatgrass (Bromus tectorum). The UNSAT-10 model simulations confirmed that coarse-textured soils could transmit water below plant root zones. Although the average annual rainfall at the Hanford site is $16 \mathrm{~cm}$, the 1983 test year precipitation exceeded $28 \mathrm{~cm}$ with nearly three-fourths of the precipitation occurring during five winter months (January, February, March, November, 
December). The moisture content at all depths in the soil increased to maximum values and the monthly average potential evapotranspiration were lowest during these five months.

Moisture content profiles were measured at depth, with a down-well neutron probe, at biweekly intervals from January 1983 through June 1984, and these data were used to estimate drainage from the profile. Grass roots were not found below $1 \mathrm{~m}$, hence, moisture changes below $1 \mathrm{~m}$ were assumed to be caused primarily by drainage. Upward capillary flow was considered negligible because the soil was a coarse sand and the water table was below $10 \mathrm{~m}$. The large amount of drainage from this arid site is attributed to rainfall distribution pattern, shallow root zone, and soil drainage characteristics. These observations confirm earlier observations by Cline, Uresk and Rickard (1977) that drainage can occur below grass-covered areas at the Hanford site.

Simulations using the unsaturated flow model predicted about $5 \mathrm{~cm}$ of drainage from the grass site using daily climatic data, measured soil hydraulic properties, and estimated transpiration parameters for cheatgrass at the Hanford site. Improvements in the comparisons between measured and predicted drainage are anticipated with more direct measurements of grass cover transpiration. However, both measurements and model predictions support the conclusion that under conditions where above average rainfall occurs during periods of low potential evaporation and where soils are coarse, significant drainage can occur from the root zone at an arid site.

Waste management at arid sites in the western United States will require that special attention be paid to soil characteristics, precipitation distribution, and plant cover to adequately predict site-specific recharge rates. Infiltration barriers may be required at sites where recharge is found to be significant. The UNSAT-10 model appears to be a useful tool in assessing unsaturated-zone recharge at arid sites. 


\section{CONTENTS}

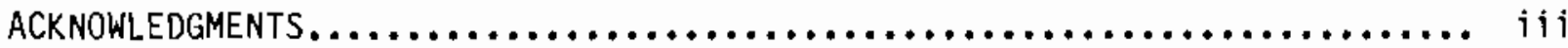

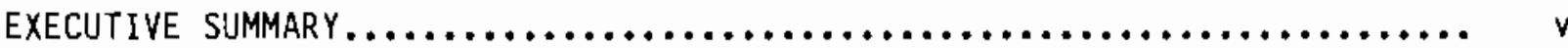

INTRODUCTION................................................. 1

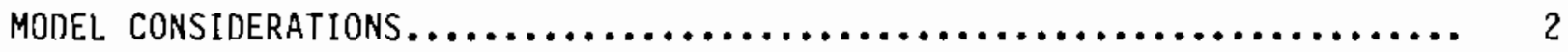

BASIC CONCEPTS OF UNSATURATED FLOW MOOELING...................? ?

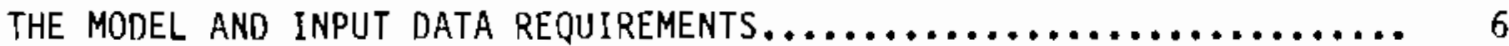

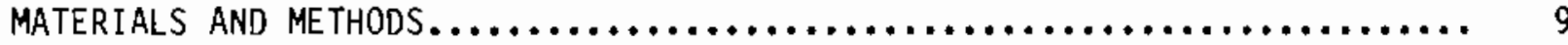

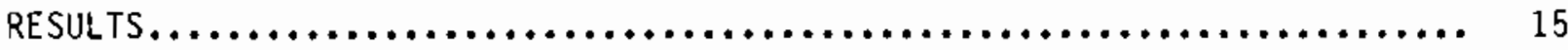

PRECIPITATION............................................. 15

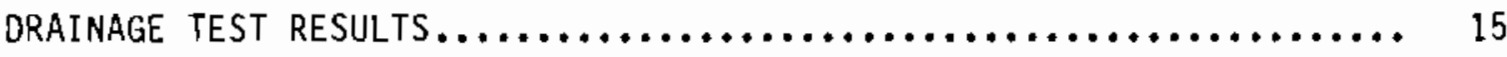

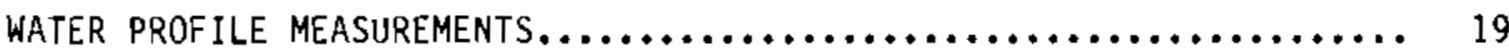

LYSIMETER DRAINAGE $\ldots \ldots \ldots \ldots \ldots \ldots \ldots \ldots \ldots \ldots \ldots \ldots \ldots \ldots \ldots \ldots, 23$

MDDEL SIMULATIONS........................................... 26

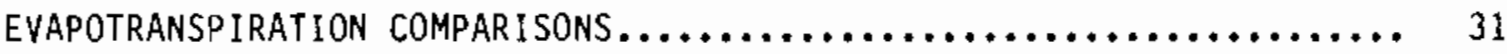

DISCUSSION.................................................. 33

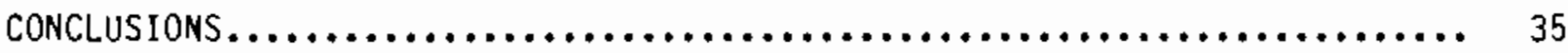

REFERENCES.............................................. 36

APPENDIX A - PNL PUBLICATIONS RELATED TO TRANSPORT ASSESSMENT - ARID..... A.1 


\section{FIGURES}

1. Location of Hanford Site and Research Sites................... 10

2. Location of Access Wells and Instrumentation at Grass Site........ 12

3. Rainfall of Years 1979 Through 1984 at the Hanford Site........... 16

4. Precipitation at Grass Site and Hanford Meterological Station During 1983........................................... 17

5. Water Content Versus Time for the Instantaneous Profile Experiment........................................... 18

6. Water Content Versus Time for the Instantaneous Profile

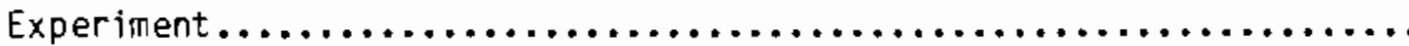

7. Hydraulic Conductivity of Grass Site Soils as a Function of Water Content.

8. Water Storage at the Grass Site in 0 - to $1.0,1-$ to $3.5-$, and $0-$ to $3.5-m$, Layers.................................. 21

9. Water Content Profiles at Grass Site During 1983, Wetting Period..... 22

10. Water Content Profiles at Grass Site During 1983, Drying Period..... 23

11. Water Content Changes at Selected Depths at Grass Site............ 24

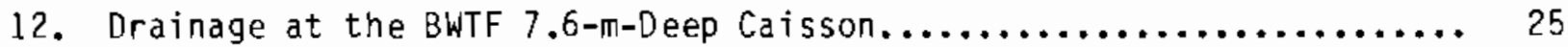

13. Drainage from the Bare Soil Lysimeter at BWTF................ 25

14. Cumulative Drainage at South Weighing Lysimeter.............. 26

15. Measured and Modeled Water Storage Changes for One Layer of Soil at Grass Site...................................... 29

16. Water Content Profiles at Grass Site..................... 30

17. Calculated Water Content Changes at Grass Site Since

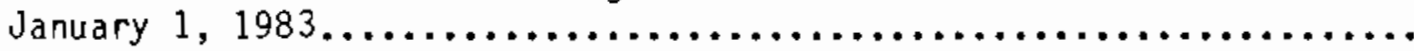

18. Model Simulation of Water Content Changes with Depth at Grass Site Using Two-Layer Model. 


\section{INTRODUCTION}

Shallow land burial is the primary disposal method for low-level radioactive waste. Sites in the arid west, where precipitation is low and where thick, unsaturated soil zones persist, are generally considered the most ideal for this type of waste disposal (Mercer, Rao and Marine 1983). These sites provide an environment that tends to minimize contact of water with the waste, thereby minimizing the potential problem of ground-water contamination.

There has been considerable interest in documenting the amount of water flow that actually occurs at depth in the unsaturated zone at arid sites (Brownell et al. 1975; Jones 1978; Winograd 1981). Estimates of water flow rates in the unsaturated zone at the Department of Energy's Hanford site (Washington) and Nevada Test Site have generally ranged from a few millimeters or less, to slightly over $1 \mathrm{~cm} / \mathrm{yr}$ (Winograd 1981; Jones 1978; Wallace 1978). Detailed water balance studies at these arid sites are needed to better quantify the amounts of water that may be available for the transport of radionuclides.

Recent lysimeter studies (Jones, Campbell and Gee 1984) at the Hanford site indicate that significant quantities of water flow (in excess of $5 \mathrm{~cm} / \mathrm{yr}$ drainage) can occur in bare soils under arid conditions (16 to $25 \mathrm{~cm}$ of annual precipitation). However, most burial sites will likely have some vegetative cover, which can transpire significant quantities of water, thus, reducing the amount available for drainage. To evaluate drainage at an arid site, we measured the water balance of a grass-covered site and used the unsaturated flow model, UNSAT-1D, to simulate water balance at the site. This report is structured in the following manner: 1) basic considerations for unsaturated flow modeling are presented; 2) the unsaturated flow code, UNSAT-1D, and its input data requirements are discussed; 3) the field measurements and methods for calculating water balance are presented; and 4) the field test results are compared with those from model simulations. 
MODEL CONSIDERATIONS

The following section contains a detailed analysis of how water flows through unsaturated soil. The concept of modeling water flow in an unsaturated hydrologic zone is explained, and the data input requirements are listed.

\section{BASIC CONCEPTS OF UNSATURATED FLOW MODELING}

To understand unsaturated-flow modeling, the physical mechanisms involved must be reviewed. Although in this report we simplify unsaturated-flow modeling into a one-dimensional analysis, the process is mechanisticaliy complex. The unsaturated zone constitutes the transition region between the atmosphere and a ground-water system. Passage of water through this zone is very dynamic and depends on detailed variations in the hydraulic properties of the water in the soil (hereafter referred to as soil water). Precipitation in the form of rain and snow falling directly on the soil surface is usually viewed as the primary water input to this zone, but water from irrigation can also contribute substantial input.

Water moves downward through soil under the influence of gravity as long as sufficient water is present to overcome the restraining forces in the porous soil matrix (described rigorousiy as capillary or matric potential). Water is extracted from the unsaturated zone through surface evaporation and by roots of actively transpiring plants. The rates of both extraction processes depend directly on available solar energy (heat radiation), surface winds, and atmospheric vapor density.

Water moves through soil via two physical mechanisms: capillary Darcian flow (liquid phase) and vapor diffusion. Darcian flow is described by hydraulic conductivity and matric potential gradients, both of which manifest extreme variation with even small changes in water content. Vapor diffusion results from thermal gradients and is mainly important near the soil surface where it controls actual surface evaporation. Maximal potential evaporation rates estimated by energy balance methods such as Penman's (Penman 1948) can be realized only when sufficient water is near the soil surface; otherwise, a dry soil layer limits evaporation. 


\section{Soil Water Flow}

A soil is saturated when all void space (i.e., space not occupied by soil particles) is filled with water. An unsaturated soil contains air-filled void space as well as water. The measure of water quantity contained by a soil is called water content, which is the volume of water per unit of soil bulk volume. Part of the water in an unsaturated soil will exist as vapor contained in the air-filled pore space, with the amount depending on soil temperature. In view of the greater density of liquid water, relatively moist soils will contain a comparatively small amount of vapor. Water moves in an unsaturated soil as both liquid and vapor. The movement is always directed from regions of higher to those of lower potential energy (water potential) when isothermal conditions prevail. Total water potential is expressed as

$$
\psi=\psi_{p}+\psi_{s}+\psi_{m}+\psi_{z}
$$

where $\psi_{p}, \psi_{s}, \psi_{m}$, and $\psi_{z}$ are the pressure, solute, matric, and gravitational potentials, respectively. Pressure potential represents external mechanical forces; solute potential represents the attraction forces of water to higher solute concentration (osmotic forces); matric potential represents the adsorptive forces of the soil; and gravitational potential is the energy associated with the water's location in the earth's gravity, measured with respect to some reference point that is usually taken at the soil surface. The negative of the gradient of total potential is the force causing water movenent in a soil. In most cases the pressure and solute potential are not present (equal to zero), and the total potential is then called hydraulic potential. When the quantity of water is expressed as weight, the units of potential are centimeters of water. The matric potential, $\Psi_{m}$, is a negative quantity and can be expressed in terms of a pressure head, $-h$, where $h$ is the positive suction head (Richards 1965). In a horizontal soil column, water moves from lower toward higher suction heads. The relationship between pressure head and water content is called the soil water characteristic curve. This curve is distinct for each soil and is required by the model as input information. A characteristic curve is usually not a single-valued functional relationship because hysteresis effects 
effects cause different matric potential values or energy states to be associated with a particular water content, depending on whether a soil was dried or wetted to that water content.

Water moves through different soils at different rates for the same hydraulic potential gradient. The hydraulic conductivity, denoted $K(\theta)$, represents the ability of a soil to transmit water at different rates from wet to dry locations. One-dimensional water flux, $q_{L}$, is described in terms of $K(\theta)$ by Darcy's law:

$$
q_{L}=-K(\theta)\left(\frac{\partial \psi}{\partial z}\right)
$$

Hydraulic conductivity, which is a positive function of water content, $\theta$, decreases rapidly by many orders of magnitude from its maximum saturated value as water content decreases. Units of hydraulic conductivity are $\mathrm{cm} / \mathrm{hr}$ or $\mathrm{cm} / \mathrm{s}$, when potentia1, $\psi$, and depth, $z$, are expressed in $\mathrm{cm}$. Water flux per unit area [Equation (2)] has the same units. Combining Darcy's law--Equation (2)-with the equation for water conservation and expressing potential in terms of suction head, $h$, gives the flow equation

$$
c(h) \frac{\partial h}{\partial t}=\frac{\partial}{\partial z}\left[K(h)\left(\frac{\partial h}{\partial z}+1\right)\right]+S(z, t)
$$

The term $c(h)$ is equal to $\frac{-d \theta}{d h}$ and defined as the soil water capacity with units of $\mathrm{cm}^{-1}$. $K(h)$ is expressed explicitly as a function of $h$ by means of the soil water characteristic, which is usually represented by a single drying curve; and $S(z, t)$ is a plant root sink term in units (cm water per cm soil/hr). Depth, $z$, in Equation (3) is positive downward from the surface, and soil water flux is given by

$$
q_{L}=K(h)\left(\frac{\partial h}{\partial z}+1\right)
$$


which is positive in the downward direction. The soil water flow model is described by a finite-difference representation of Equation (3) for each soil layer by using an implicit-difference solution scheme for $h$, calculated over the profile at each time step. Mathematical description and details of the UNSAT-1D model are provided elsewhere (Simmons and Gee 1981; Bond, Freshley and Gee 1982).

The fundamental assumption used in solving Equation (3) is that matric potential is a continuous physical quantity in the transition between soil layers. On the other hand, this implies that there is a discontinuous behavior of water content between layers. Accuracy of the finite-difference solution is controlled by the mass balance error allowed over the nodal representation of the soil profile. An interested reader can refer to excellent text books on soil physics (Hillel 1982; Marshall and Holmes 1979; Hanks and Ashcroft 1980) for further clarification of soil water flow concepts and measurement of soi] water properties. Hydraulic Properties of Soil Water

The soil water characteristic curves and hydraulic conductivities are required to describe unsaturated water flow. Measurements and calculated estimates of these properties are represented in the UNSAT-10 model by polynomial functions that have been least-squares fitted to the data. Polynomial representations used in the computer program avoid large data storage requirements associated with many soil layers and provide a convenient interpolation method. Details of the polynomial descriptions are provided elsewhere (Simmons and Gee 1981; Bond, Freshley and Gee 1982). Where soil water characteristics can be considered to be represented by exponential type relationships, simpler expressions can be used (see Mckeon et al. 1983). An obvious requirement is that data on soil water properties must cover the range of water contents expected to be encountered in a particular simulation.

Water Storage

Water storage by a soil profile is characterized by a water content distribution with depth. The distribution at any time depends ultimately on the detailed spatial variability of hydraulic properties and the flux and temporal 
distribution of any flux of water at the profile boundary. Infiltrating water that exceeds soil water holding capacity at a particular profile location will contribute to deep drainage, which inay possibly enter the ground water depending on depth of the water table. Therefore, a single set of measured hydraulic properties cannot correctly represent an areal region. An estimate of the statistical distribution is required to determine areal drainage flux. The presence of soil layers further complicates the modeling of unsaturated flow. Soil layers consisting of a variety of distinct media such as clay, siit, sand, and gravel have a physically deterministic effect on water movement patterns. Some layers will rapidly transmit and others will impede soil water movement. On the other hand, the location and types of various soil layers may be stochastically unknown in a natural soil profile. Such variability contributes substantialiy to the uncertainty in making predictions about unsaturated flow.

Growing plants are powerful and efficient extractors of stored water. The relationship between potential transpiration and climatic conditions must be quantified in an unsaturated-zone simulation. Active plant roots have a water withdrawal distribution that also must be taken into account. Indeed, estimating water balance over an areal region accurately is impossible without quantifying and modeling transpiration and root growth in detail.

\section{THE MODEL AND INPUT DATA REQUIREMENTS}

The UNSAT-1D computer model (Gupta et al. 1978) was originally developed to describe vertical, one-dimensional, unsaturated water movement under typical agricultural conditions. It was designed as a model for isothermal (i.e., uniform temperature) water flow in the liquid phase. Many models with similar objectives are reported in the literature [e.g., Nimah and Hanks (1973), Hillel (1977), and Feddes et al. (1976)]. A model application by Kiute and Heermann (1978) suggested an extension to include isothermal vapor flow. All unsaturated flow models depend on the quantity and quality of crucial site-specific input data. Physical phenomena for which no supporting numerical information is available cannot be modeled, regardless of how complex the model is. In view of the continued revisions to unsaturated flow theory and technology, models should be considered as research tools to aid understanding and shoutd 
not be interpreted beyond the limitations of input data. A review by Molz, Davidson and Tollner (1979) provides an outline for the current understanding of unsaturated flow.

We used the UNSAT-1D model for this study because it allows us to describe the soil water flow processes clearly and account for time-dependent (transient) behavior that typically controls soil water movement at arid sites.

The following input information is necessary to define an unsaturated flow model simulation of a specific site:

- depth of the soil profile and location of each soil layer. The maximum depth is the lower boundary condition location.

- type of lower boundary condition specified as a water table or free drainage situation. Free drainage conditions are applicable if the water table is actually deep below the simulated profile.

- the soil hydraulic properties defined by a soil water characteristic curve (water retention relationship) and hydraulic conductivity/water content relationship for each soil type present in the profile.

- the rainfall and potential evapotranspiration for each day of the simulation period, including the pattern of diurnal variation. Rainfall should be by hour, and diurnal variation should be expressed as a fraction of daily amounts for each hour.

- properties of the soil-surface vapor-diffusion layer that forms when soil has attained air-dry conditions. These properties include layer thickness and characteristic vapor diffusivity. A water content limit for layer formation is required.

- the initial water content distribution over the soil profile as established by a water movement history or direct measurement.

- an optional, measured, soil temperature distribution if nonisothermal vapor flow conditions are important. A distribution is required for each period with substantial alteration in temperature. 
- plant growth and water extraction behavior. This information must include a root density distribution as a function of the growth period and actual transpiration as some factor of the potential value when water is not limited.

The above list represents a considerable amount of data. The difficulty of unsaturated flow modeling is that some of the data usually cannot be measured directly, and so must be estimated by various theoretical methods. The major advantage of an unsaturated flow code is the ability to incorporate known processes (e.g., infiltration, evaporation, redistribution) that control the water flow and transport at a given site so that the effects of these processes on contaminant migration can be quantified. 


\section{MATERIALS AND METHODS}

A vegetated area located on the Hanford site, near Richland, Washington, was selected for the water balance study. The location of the grass study area is shown in Figure 1. The site is located in a slight depression approximately $900 \mathrm{~m}$ wide and several thousand meters long in a northeast-southwest direction. A range fire several years ago removed brush species from the site, so that brush growth now appears only at the burn area perimeters. The vegetation community of grasses is quite typical of disturbed areas on the Hanford site where natural revegetation has occurred. The vegetation is composed primarily of a mixture of two grass species: cheatgrass (Bromus tectorum) and Sandberg's bluegrass (Poa sandbergii), comprising $35 \%$ and $27 \%$ of the total cover, respectively. The cover estimates were made using a canopy-cover method described by Daubenmire (1959). The growth of both grasses is confined to late fall and early spring. The soil is well drained and nearly uniform to a depth of 3.5 $\mathrm{m}$. The top $0.6 \mathrm{~m}$ contains $79 \%$ sand, $17 \%$ silt, and $4 \% \mathrm{clay}$ and is classed as a loamy sand. From 0.6 to $3.5 \mathrm{~m}$, the soil contains $92 \%$ sand, $5 \%$ silt, and $3 \%$ clay and is classed as a sand. A rock/gravel layer lies below the $3.5-m$ depth. The rock/gravel layer is estimated to be several meters thick from observations of excavations at adjacent sites. The water table is below $10 \mathrm{~m}$.

Water balance data at the site are collected by recording precipitation events; monitoring other meteorological variables, including air temperature, humidity, and wind speed; measuring the soil profile water content; and measuring evapotranspiration losses from weighing lysimeters at the Buried Waste Test Facility (BWTF) site. Precipitation is measured with both a collection rain gauge of plastic and a tipping bucket connected to a CR-21 data logger (Campbell Scientific Inc., Logan, Utah) that records the time of each $0.25-\mathrm{mm}$ increment of rainfall. Hourly and daily relative humidity and maximum and minimum air and soil temperatures are also collected at the site. Additional climatic data, including solar radiation, are available from the Hanford Meterological Station, approximately $27 \mathrm{~km}$ northwest of the grass site. 


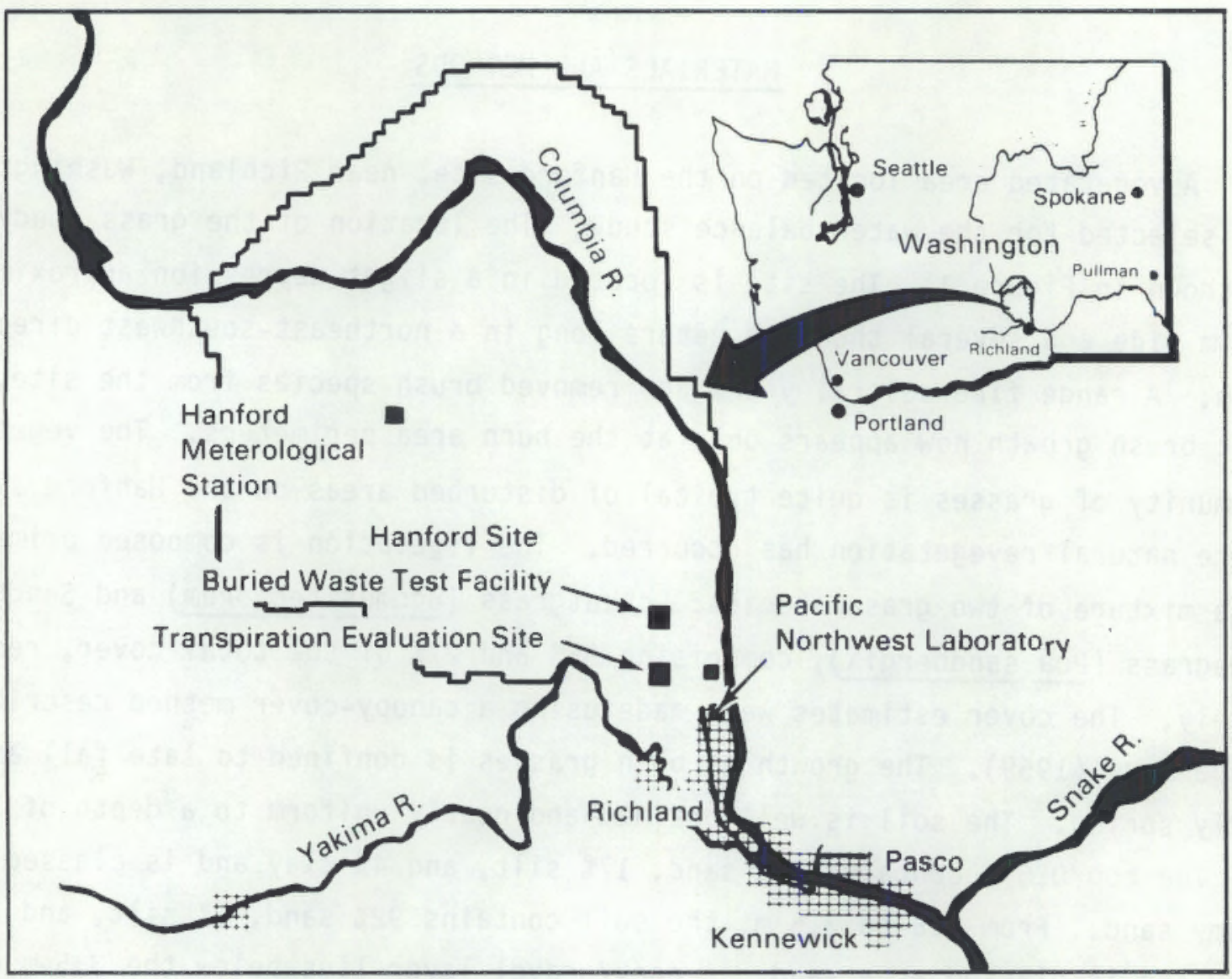

FIGURE 1. Location of Hanford Site and Research Sites

Soil moisture measurements were made with a down-well-type neutron moisture probe. The neutron probe, Model 503 (Campbell Pacific Nuclear Inc., Pacheco, California), was field calibrated by converting gravimetric moisture data to volumetric water content from samples collected during installation of access tubes in December 1982 and performing a regression of probe-count ratio against volumetric water content for all samples collected below $30 \mathrm{~cm}$. The calibration moisture data ranged from $5 \%$ to $20 \%$ by volume. Soil samples collected during the summer of 1983 at 30-, 60-, and 90-cm depths adjacent to access tubes confirmed that the calibration was adequate, even for relatively dry soil ( $<5 \%$ by volume).

Neutron probe measurements were taken at $15-\mathrm{cm}$ intervals to a depth of $165 \mathrm{~cm}$ and at $30-\mathrm{cm}$ intervals down to $345 \mathrm{~cm}$. Soil moisture values determined by the neutron moisture probe were converted to an equivalent water depth by 
multiplying each volumetric moisture content by the appropriate depth interval of 15 or $30 \mathrm{~cm}$. These values were then summed to produce the water content for the soil profile layers of interest. Data sets collected from the probe were entered in an interactive data base/plotting program on a VAX 11/780 computer. The program generates summary tables and plots to provide a profile of average volumetric water for each sampling interval and water content through time for the field site.

Soil profile moisture was measured at approximately 2-week intervals at 25 neutron access wells installed in a $5-b y-5$ grid with $6-m$ spacing between wells. Standard deviations of the mean at each sample interval ranged from a high of $1.5 \%$ water near the surface during the wet months to a low of $0.5 \%$ water at lower depths. The average standard deviation for the $1-$ to $3.5-\mathrm{m}$ samples was generally less than $1 \%$ volumetric water content. Because the site is uniform and a large number of locations (25) were sampled, we estimated that drainage values from the $3.5-m$ depth are good to about $0.5 \mathrm{~cm}$.

Figure 2 shows the placement of access wells and supporting instrumentation. Each well was installed at a depth of $3.5 \mathrm{~m}$ according to the following steps: driving in a split-tube sampler, then driving in the surrounding casing to the same depth, extracting the split-tube sampler, and removing soil material from the split-tube sampler. These steps were repeated approximately every $50 \mathrm{~cm}$ until the rock/gravel layer was encountered at approximately $3.5 \mathrm{~m}$. This process provided representative soil samples from each depth increment and ensured an access well with minimal disturbance to the surrounding soil material. Soil collected from each split-tube sample was returned to the lab to determine gravimetric water and root content. Roots were extracted from the soil using a flotation screening process, described by Al-Khafaf, Wierenga and Williams (1977), that uses a dispersant and salt mixture to float off organic material.

Evapotranspiration (evaporation plus transpiration) rates were measured with two weighing lysimeters located at the BWTF, $2 \mathrm{~km}$ north of the field test site (see Figure 1). One weighing lysimeter had a bare soil surface, and the other had vegetation similar to the field test site. The weighing lysimeters 


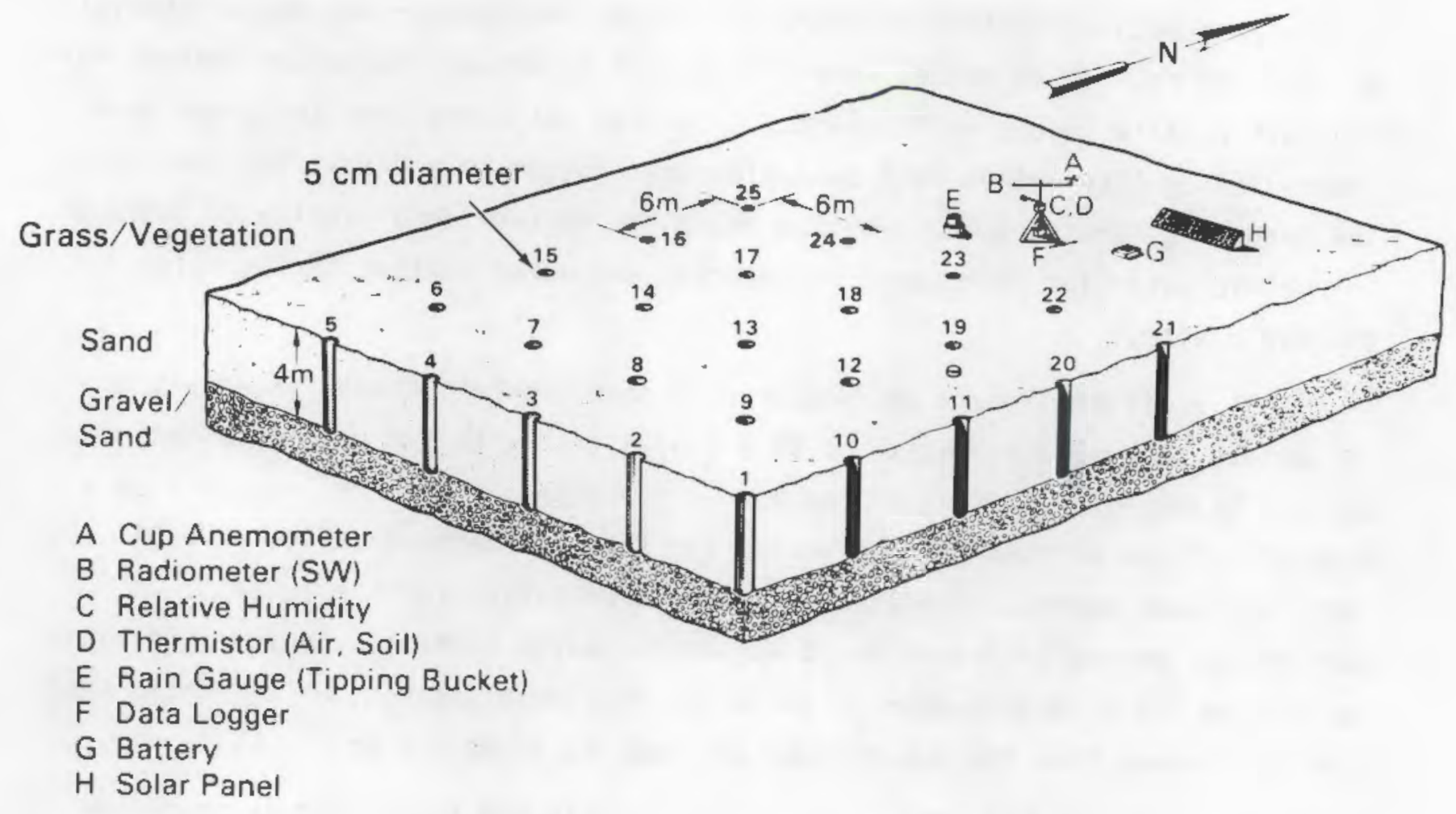

FIGURE 2. Location of Access Wells and Instrumentation at Grass Site

were fully automated and had a resolution of $50 \mathrm{~g}$, equivalent to $0.02 \mathrm{~mm}$ of water. Hourly average weights were recorded on tape and via phone lines by a laboratory computer.

Simulations of the water balance at the grass site were made using UNSAT-1D, a one-dimensional, finite-difference computer code that uses Richard's equation to calculate liquid flow of water in soil (Gupta et al. 1978; Bond, Freshley and Gee 1982). This code simulates infiltration, redistribution, and drainage using known or estimated hydraulic properties. Also included in the code are several evaporation, transpiration, and root growth algorithms. Selection of a specific algorithm to describe these processes is dependent on the sophistication of the available data.

We used a water balance approach to analyze our field data. The total water in a soil profile at any time during the year is a function of the 
starting water content, precipitation, evaporation, transpiration, internal redistribution, and water movement on or off the surface. This relationship can be expressed as

$$
W=S_{i}+P-E-T \pm D \pm R
$$

where

$$
\begin{aligned}
W & =\text { total water in the profile }(\mathrm{cm}) \\
S_{\mathbf{i}} & =\text { initial storage }(\mathrm{cm}) \\
P & =\text { precipitation }(\mathrm{cm}) \\
E & =\text { evaporation }(\mathrm{cm}) \\
T & =\text { transpiration }(\mathrm{cm}) \\
D & =\text { drainage }(\mathrm{cm}) \\
R & =\text { runoff } / \text { run-on surface }(\mathrm{cm})
\end{aligned}
$$

Three assumptions were made in adapting Equation (1) to the field test site. First we assumed that the upward movement of water below the 1-n depth was insignificant based on the following observations: the field root distribution data indicated that $99 \%$ of the root mass was located above $0.6 \mathrm{~m}$, with no roots measured below $1 \mathrm{~m}$; the low hydraulic conductivity of drained sandy soil; and the deep water table $(>10 \mathrm{~m})$. The second assumption was that only one-dimensional (vertical) flow was considered, which for this well-drained site appears appropriate. Finally, runoff/run-on were assumed to be zero because the generally level soil surfaces and sandy soils found at the site minimized ponding or lateral surface flow. No surface flow was observed during the study period. Based on these assumptions, we determined that drainage from the entire profile could be expressed as

$$
D=S-W+P-E-T
$$

For drainage below the 1-m depth, we assumed no root uptake below this depth, so that no evapotranspiration-induced storage changes were considered. Hence, the site drainage could be estimated simply by the storage changes after maximum storage occurred and can be written as 


$$
D=S_{\max }-W
$$

This value was considered a conservative estimate of site drainage because it does not consider subsequent input of drainage from the upper $1 \mathrm{~m}$ into the lower layer. 


\section{RESULTS}

\section{PRECIPITATION}

The rainfall during 1983 exceeded the long-term average by 177\%, and above-normal precipitation at the Hanford site has continued during the first half of $1984(131 \%)$. The normal precipitation distribution at the Hanford site is slightly weighted to the winter months, with $64 \%$ of the precipitation occurring between the 6-month interval of November to April. In 1983, the 5-month (January, February, March, November, December) period accounted for nearly three-fourths of the annual precipitation. Figure 3 shows the accumulated and yearly distribution of precipitation recorded since 1979. Figure 4 shows the 1983 accumulated precipitation at the grass site and Hanford Meteorologic Station, compared to a 70-year average for the Hanford site.

\section{DRAINAGE TEST RESULTS}

A field drainage experiment conducted in April 1984, provided us with data relating moisture content versus time and depth during uniform drainage. Plots of moisture content versus time, for each depth, flow time dependent drainage. It should be noted that during the course of the experiment, the maximum change in water content at any depth was only about $0.06 \mathrm{~cm}^{3} / \mathrm{cm}^{3}$. In many cases, the daily change in water content approached the precision of the neutron-probe measurement $\left( \pm 0.005 \mathrm{~cm}^{3} / \mathrm{cm}^{3}\right)$. Because the moisture content data were complete and consistent, we calculated the conductivity values assuming that a unit hydraulic gradient existed at all depths throughout the experiment. The conductivity values reported hereinafter should be regarded with this in mind.

For each depth, smooth curves were fit to the moisture content versus time data using the curve-fitting routine, HAVERFIT (McKeon et al. 1983). Figures 5 and 6 are plots of the water content data and the curves that were fit to the data for the $0.30-\mathrm{m}$ and $0.90-\mathrm{m}$ depths. The resulting equations were used to calculate the values of water content and water content change for each of the experimental measurement times. Ten time periods were selected for calculation. Conductivity values for each depth were calculated using the method of 


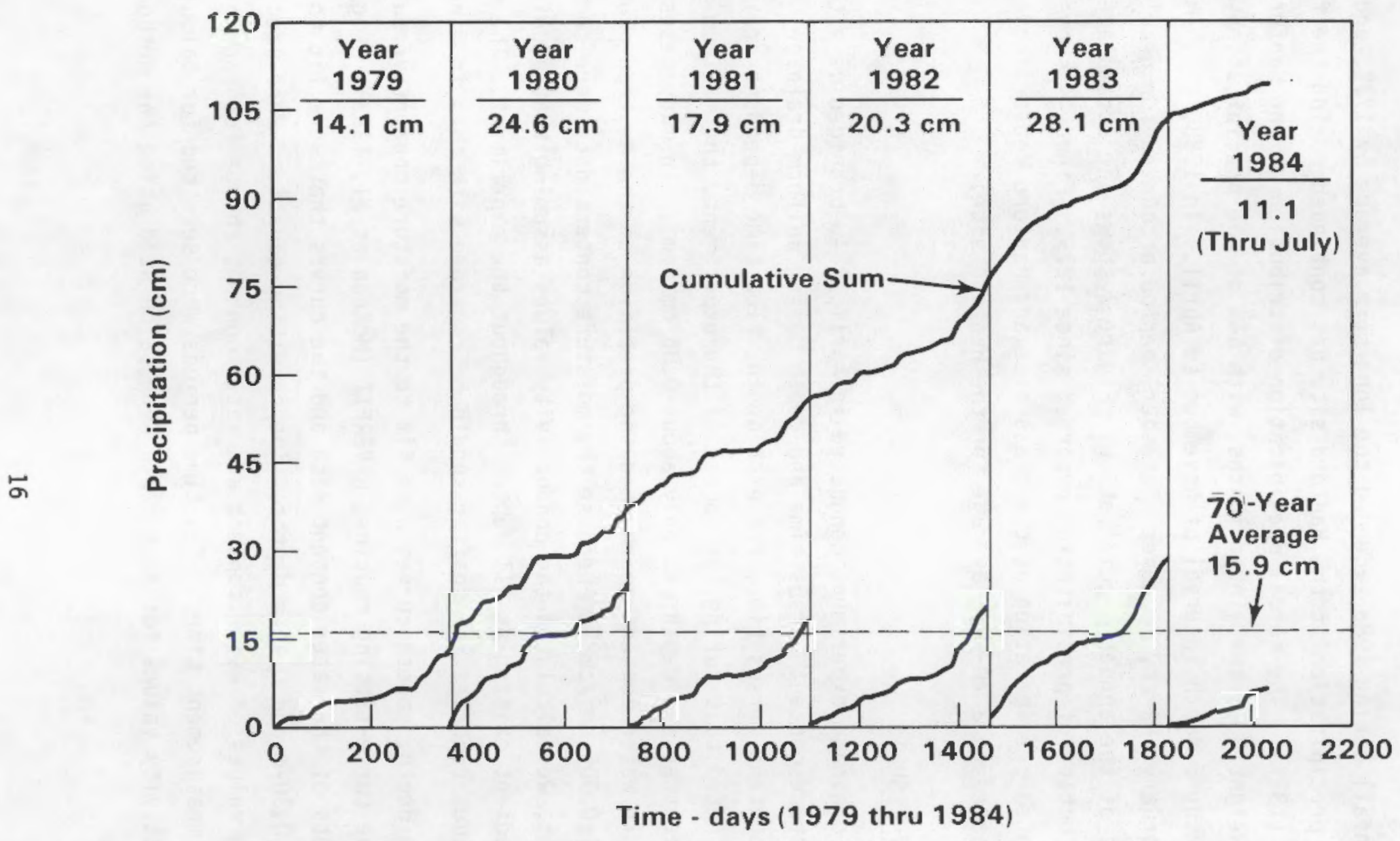

FIGURE 3. Rainfall of Years 1979 Through 1984 at the Hanford Site 


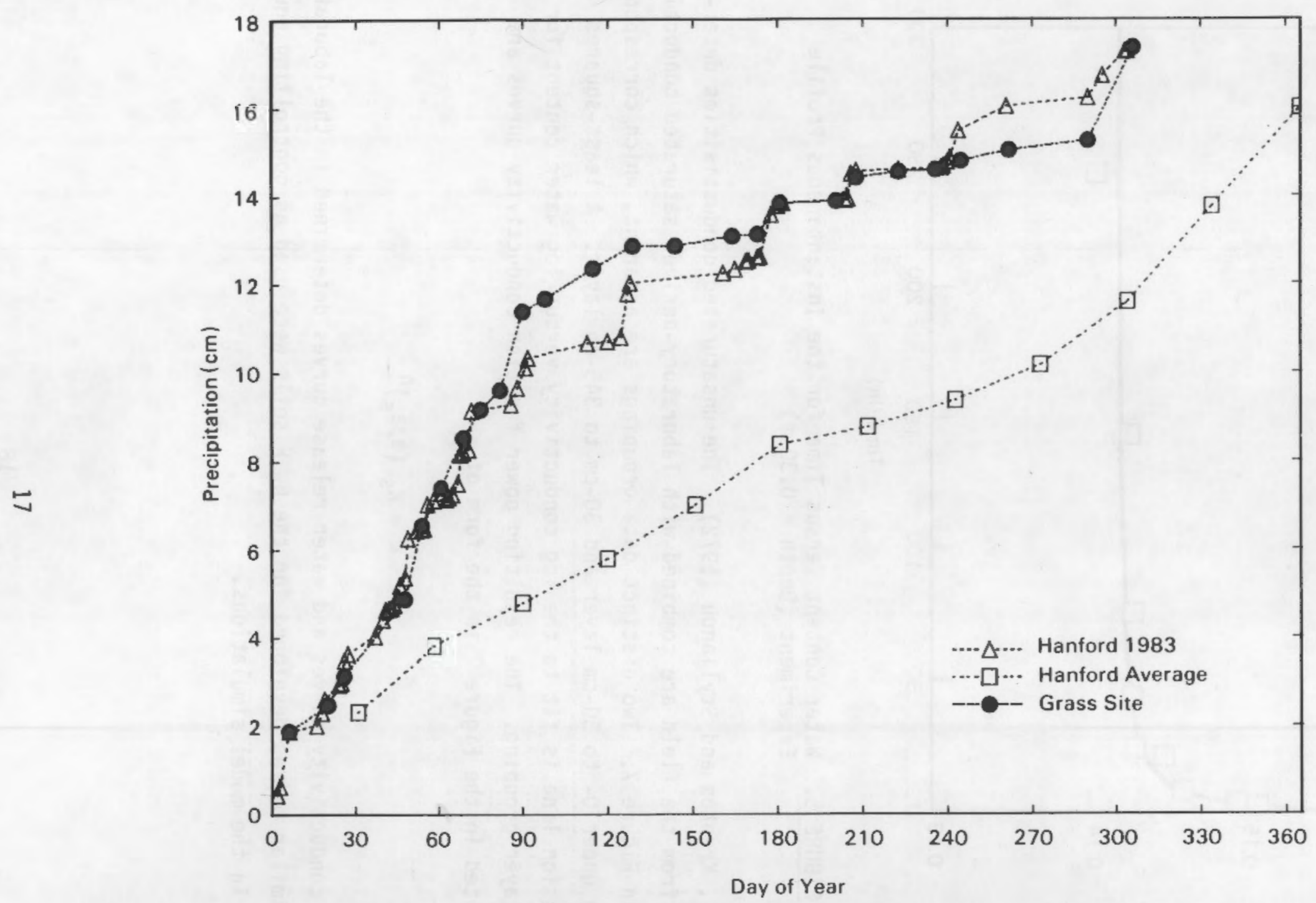

FIGURE 4. Precipitation at Grass Site and Hanford Meteorological Station During 1983 


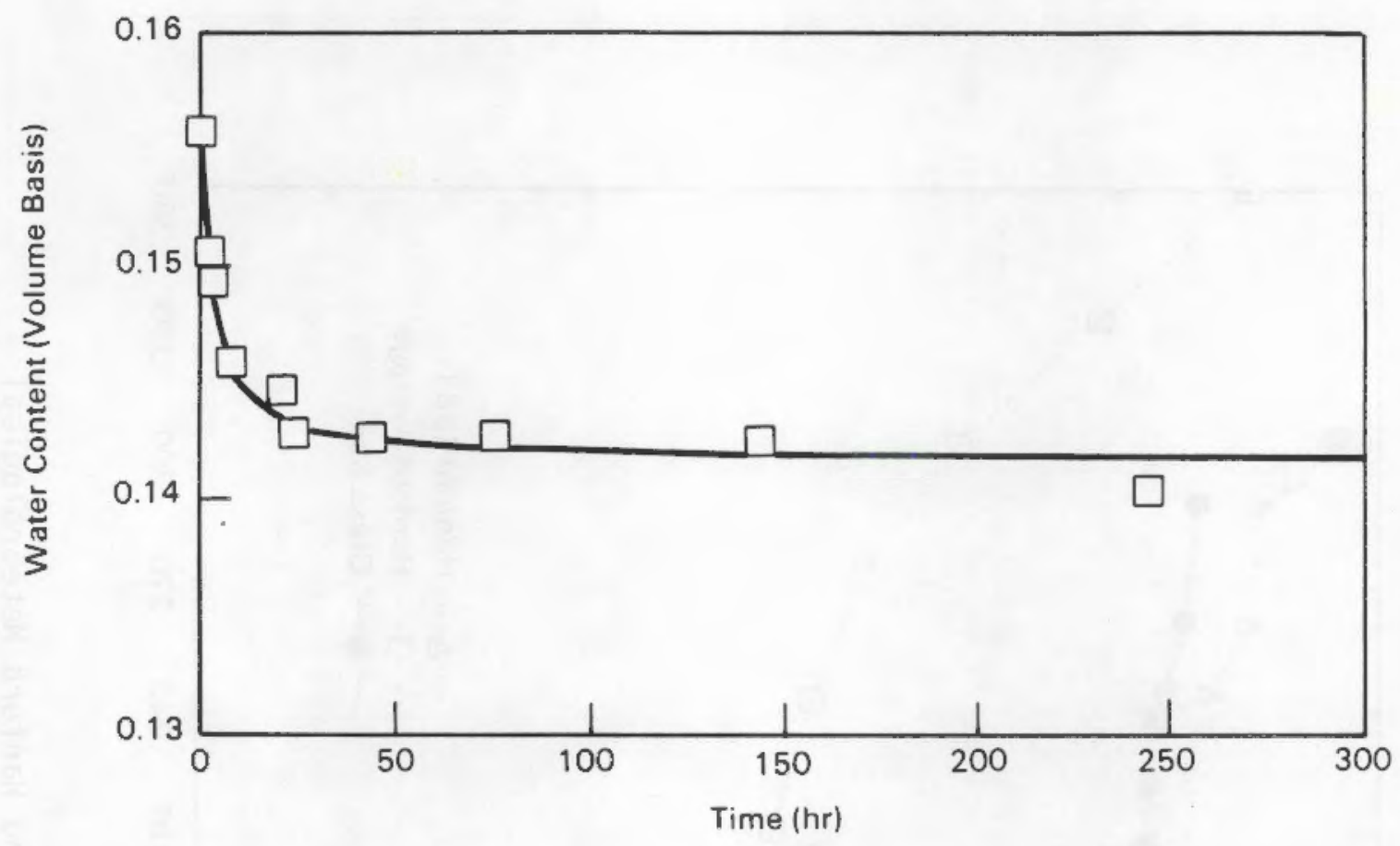

FIGURE 5. Water Content Versus Time for the Instantaneous Profile Experiment (Depth $=0.30 \mathrm{~m}$ )

Hillel, Krentos and Stylianou (1972). The unsaturated conductivities determined from the field are combined with laboratory-derived saturated conductivities in Figure 7. Two distinct data groupings are apparent, which correspond to the upper $0-$ to $30-\mathrm{cm}$ layer and $30-\mathrm{cm}$ to $345-\mathrm{cm}$ layer. A least-squares regression line is fit to the $\log$ conductivity versus $\log$ water content for each layer grouping. The resulting power function conductivity curves are presented in the Figure 7 in the form of

$$
K=K_{s}\left(\theta / \theta_{s}\right)^{n}
$$

These conductivity curves and water release curves determined in the laboratory and similar curves developed for the BWTF soils were used as controlling equations in the model simulations. 


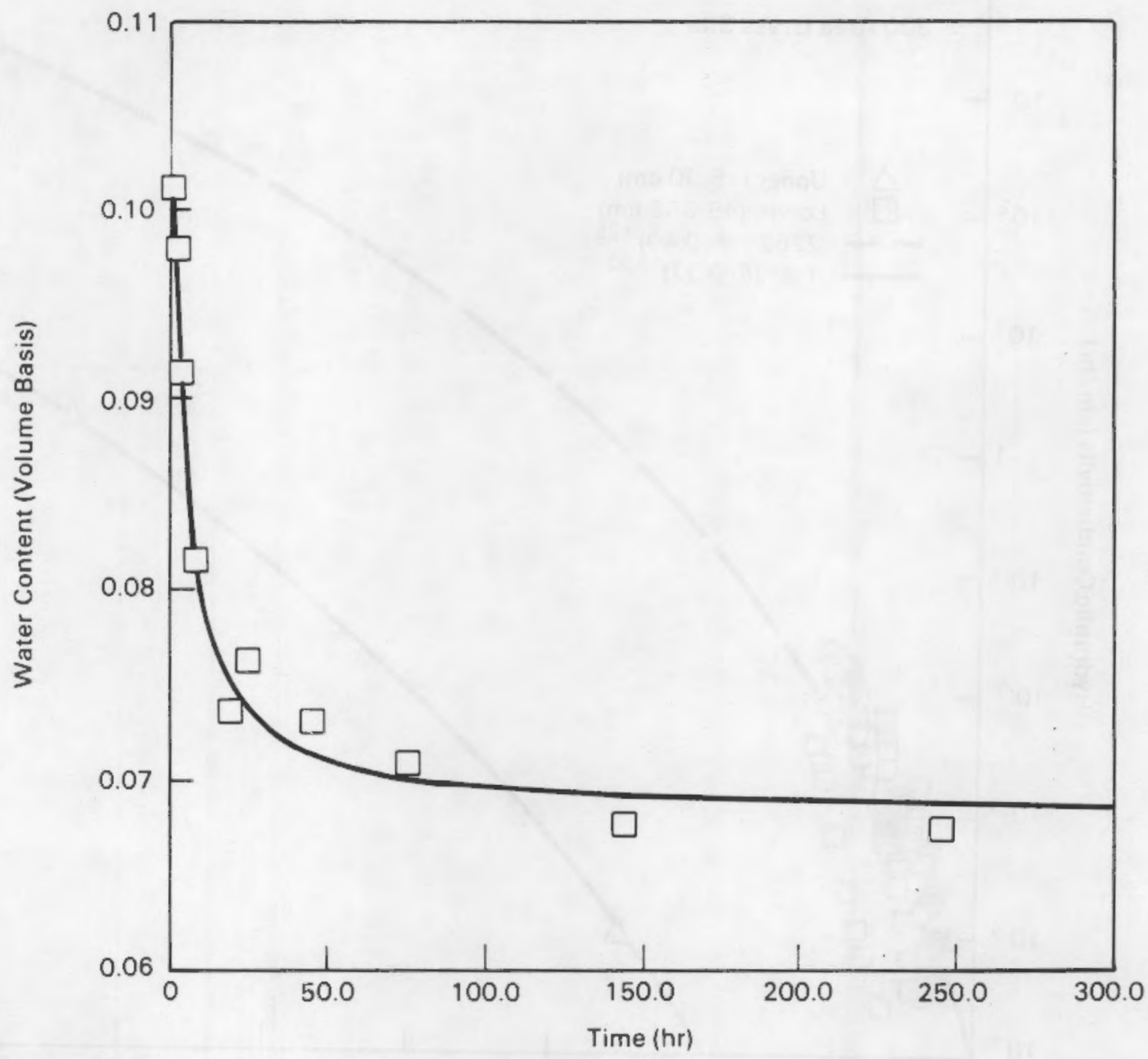

FIGURE 6. Water Content Versus Time for the Instantaneous Profile Experiment (Depth $=0.90 \mathrm{~m}$ )

\section{WATER PROFILE MEASUREMENTS}

The water content for the upper ( 0 - to $1-m$ depth) and lower (1- to 3.5-m depth) and total profile layers are plotted against time in Figure 8 . The highest water contents in the soil profile were observed on March 23, 1983 (day 82). From March 23 to October 20, 1983 (day 293), the total stored water decreased as water content diminished throughout the soil profile. Losses were assumed to be the result of evapotranspiration from the top $1 \mathrm{~m}$ of soil, of 


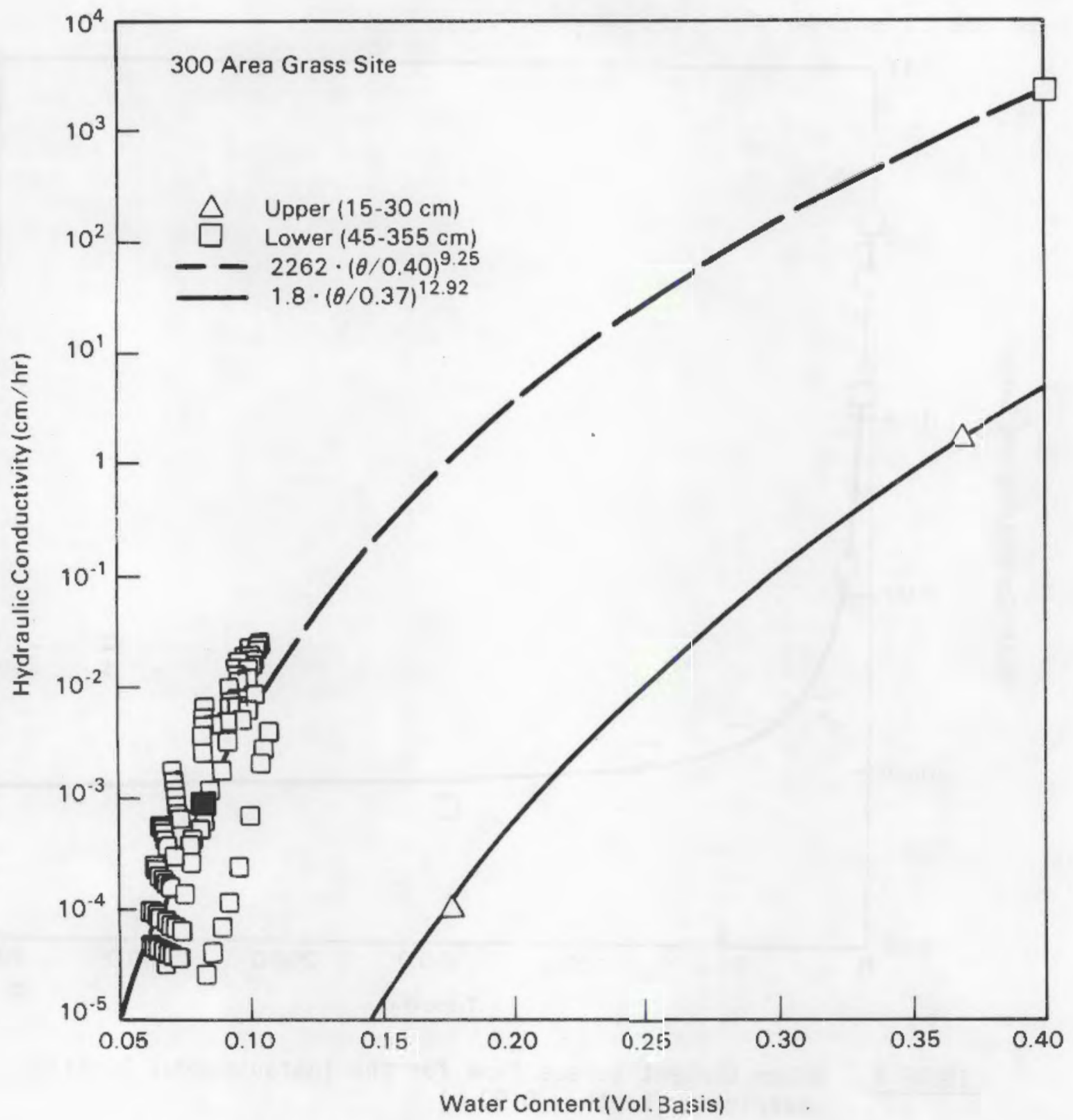

FIGURE 7. Hydraulic Conductivity of Grass Site Soils as a Function of Water Content

drainage in the upper profile, and of drainage only in the lower soil profile. During the summer months, the total water profile decreased at approximately the same rate as the lower profile, while water content in the upper layer remained relatively constant (water added by precipitation apparently equalled that lost through evapotranspiration and drainage). Assuming that the removal of water by plants is 1 imited to the upper $1 \mathrm{~m}$ of soil (the root zone) 


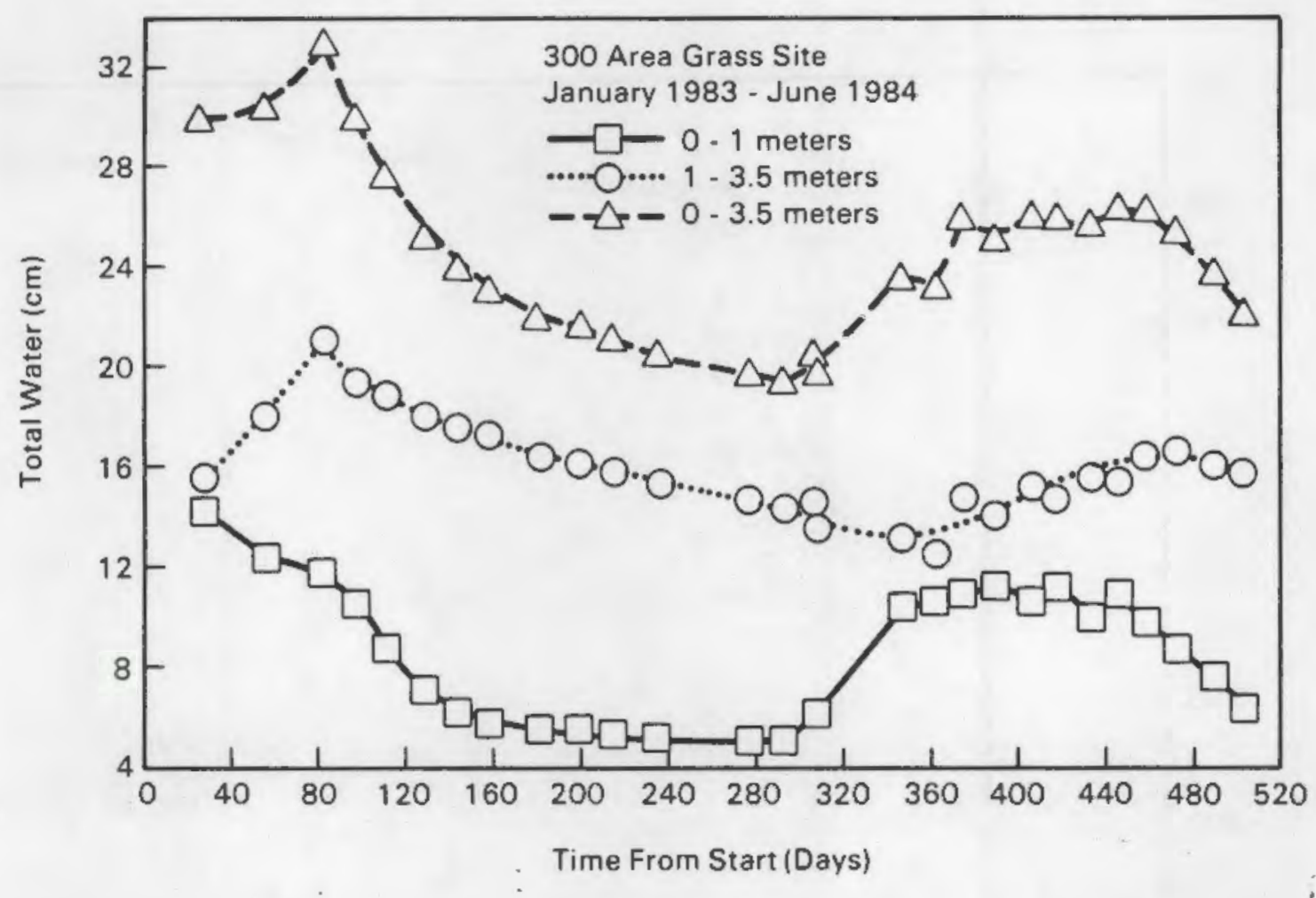

FIGURE 8. Water Storage at the Grass Site in 0- to 1.0, 1- to 3.5-, and 0 - to 3.5-m Layers

upper layer remained relatively constant (water added by precipitation apparently equalled that lost through evapotranspiration and drainage). Assuming that the removal of water by plants is limited to the upper $1 \mathrm{~m}$ of soil (the root zone) and that no significant upward redistribution of water occurs, then all water loss from the lower soil profile can be attributed to drainage. From measurements of storage differences between March 23 and December 28, 1983, we determined the drainage from the $1-$ to $3.5-\mathrm{m}$ soil layer to be a minimum of $8.5 \mathrm{~cm}$. The lower soil profile layer reaches a minimum water content 69 days after the upper profile reaches a minimum.

Measured water content profiles are shown in Figures 9 and 10; each curve represents a sampling time. Changes in water content are readily visible at the surface where large fluctuations occur through time. The increasing moisture content caused by winter rains is readily apparent in Figure 9. The moisture profile for March 23 (curve 3) is shown in both Figures 9 and 10 and represents the maximum water storage in the soil profile and the time of 


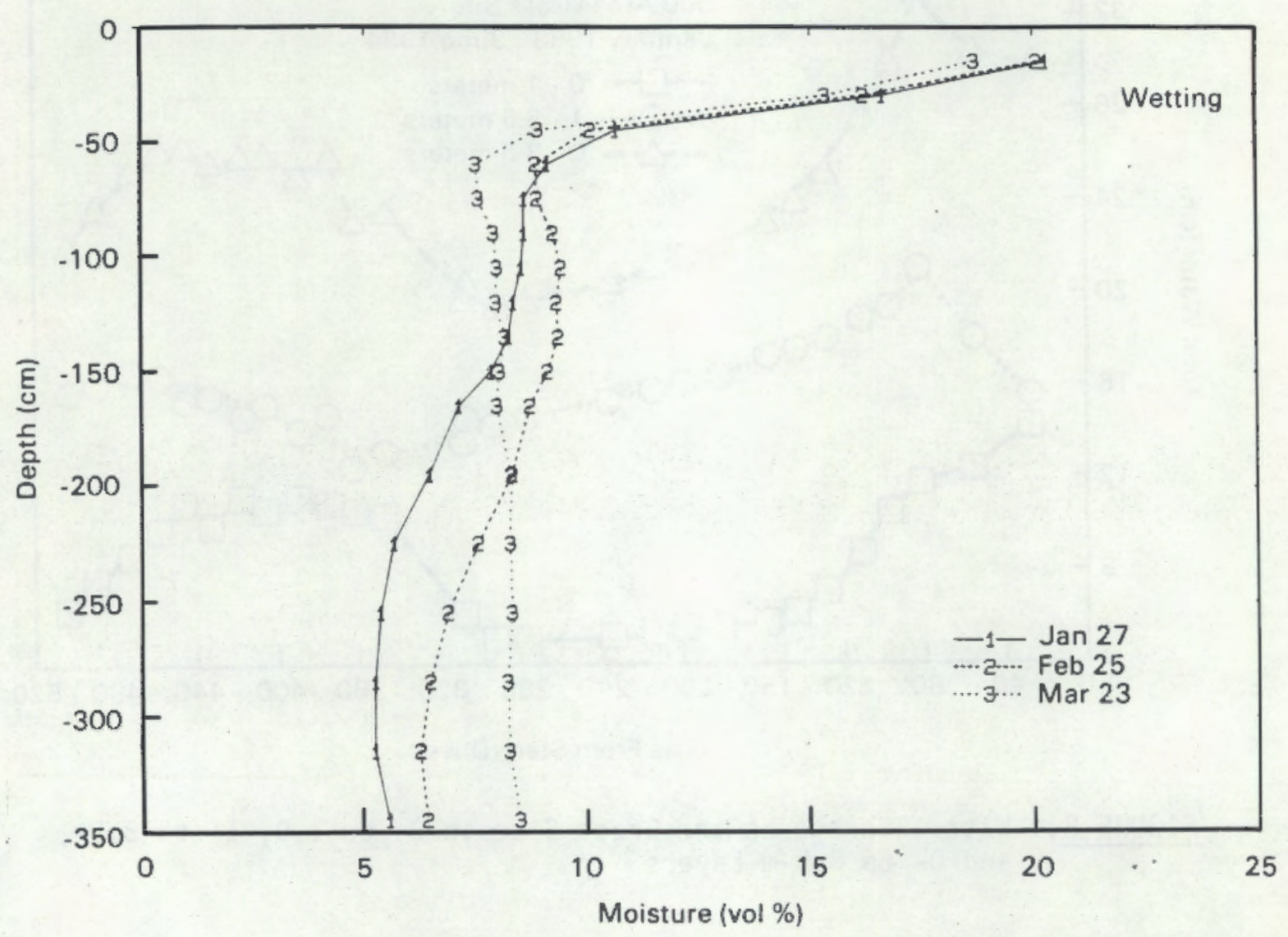

FIGURE 9. Water Content Profiles at Grass Site During 1983, Wetting Period

downward redistribution of water is apparent, showing that by october the water content is approaching the initial conditions of January. Samples from $45 \mathrm{~cm}$ and below exhibited a uniform decrease in moisture content with depth, characteristic of drainage (Davidson et al. 1969). The cyclic nature of soil water distribution is visible in Figure 11 for selected depths of $60,90,195$, and $345 \mathrm{~cm}$. The cyclic wetting and drying is readily apparent in this figure and the decreasing cycle amplitude and delayed arrival of water with depth is also visible. Observing that the soil moisture content at $345 \mathrm{~cm}$ always remains above the $5 \%$ value, and that the conductivity calculated from the field drainage test at this moisture content is $5.2 \mathrm{~cm} / \mathrm{yr}$, we find additional support for our lower profile drainage estimates of $8 \mathrm{~cm} / \mathrm{yr}$. 


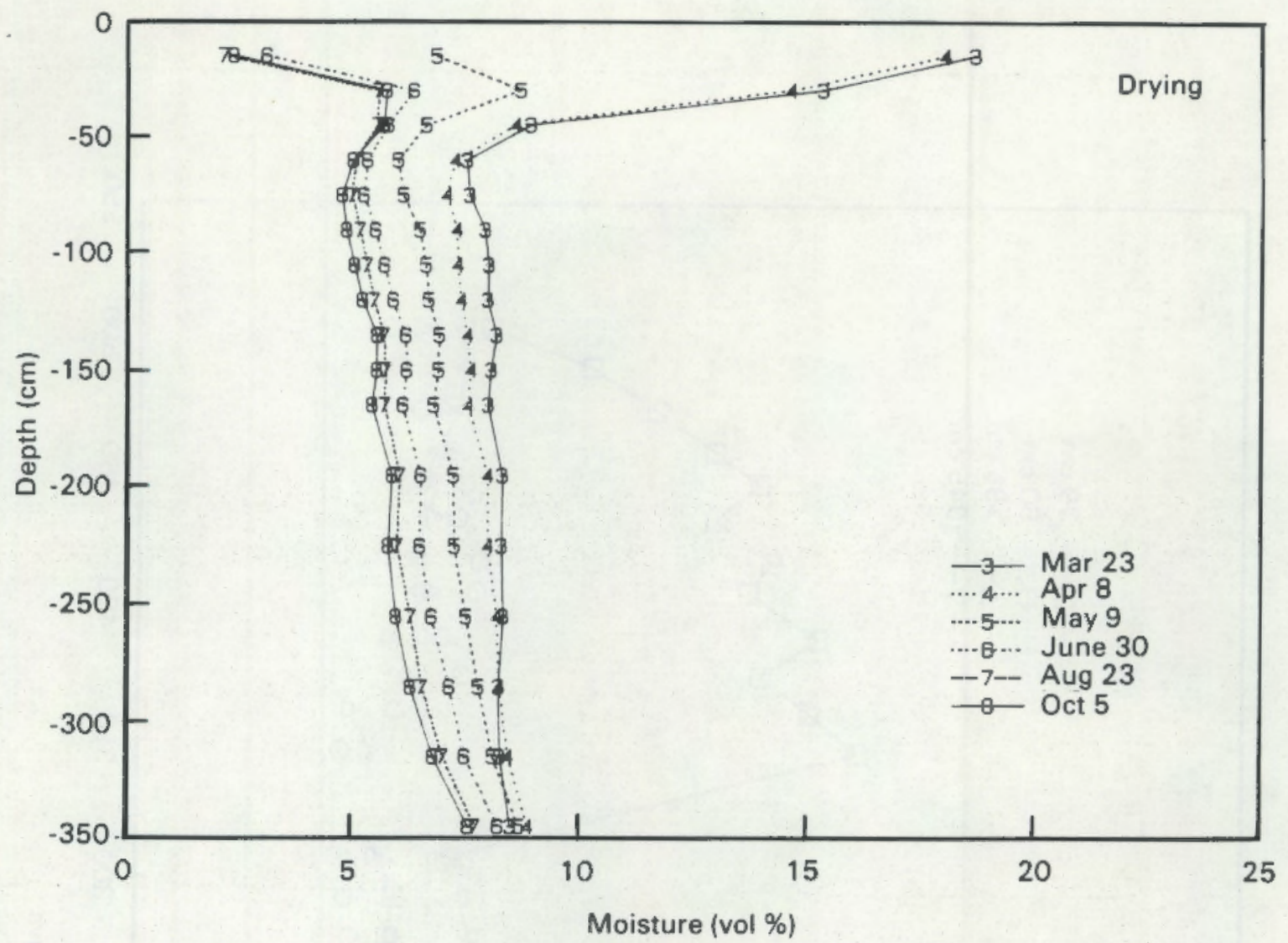

FIGURE 10. Water Content Profiles at Grass Site During 1983, Drying Period

\section{LYSIMETER DRAINAGE (BWTF)}

For comparison with the grass site, we monitored the water drained from the BWTF lysimeters (Figure 1) for the test period of 1983 and 1984. Details of earlier drainage studies are given elsewhere (Jones and Gee 1984). During 1983 and 1984, water has collected in the bottom of the north (bare) and south (vegetation) weighing lysimeters (152-cm depth) (NWL and SWL, respectively) and in the south cassion (7.6-m depth). It is important to note the NWL was observed to be leaking during the early part of 1983 and the drainage collected underestimates the actual drainage. Figures 12, 13, and 14 show the cumulative drainage collected from the BWTF lysimeters. The most direct comparison is between the grass site and the south weighing lysimeter (SWL) because only this lysimeter is vegetated (cheatgrass transplanted March 1983). Although soil type and vegetation are slightly different at SWL and the grass site, the 


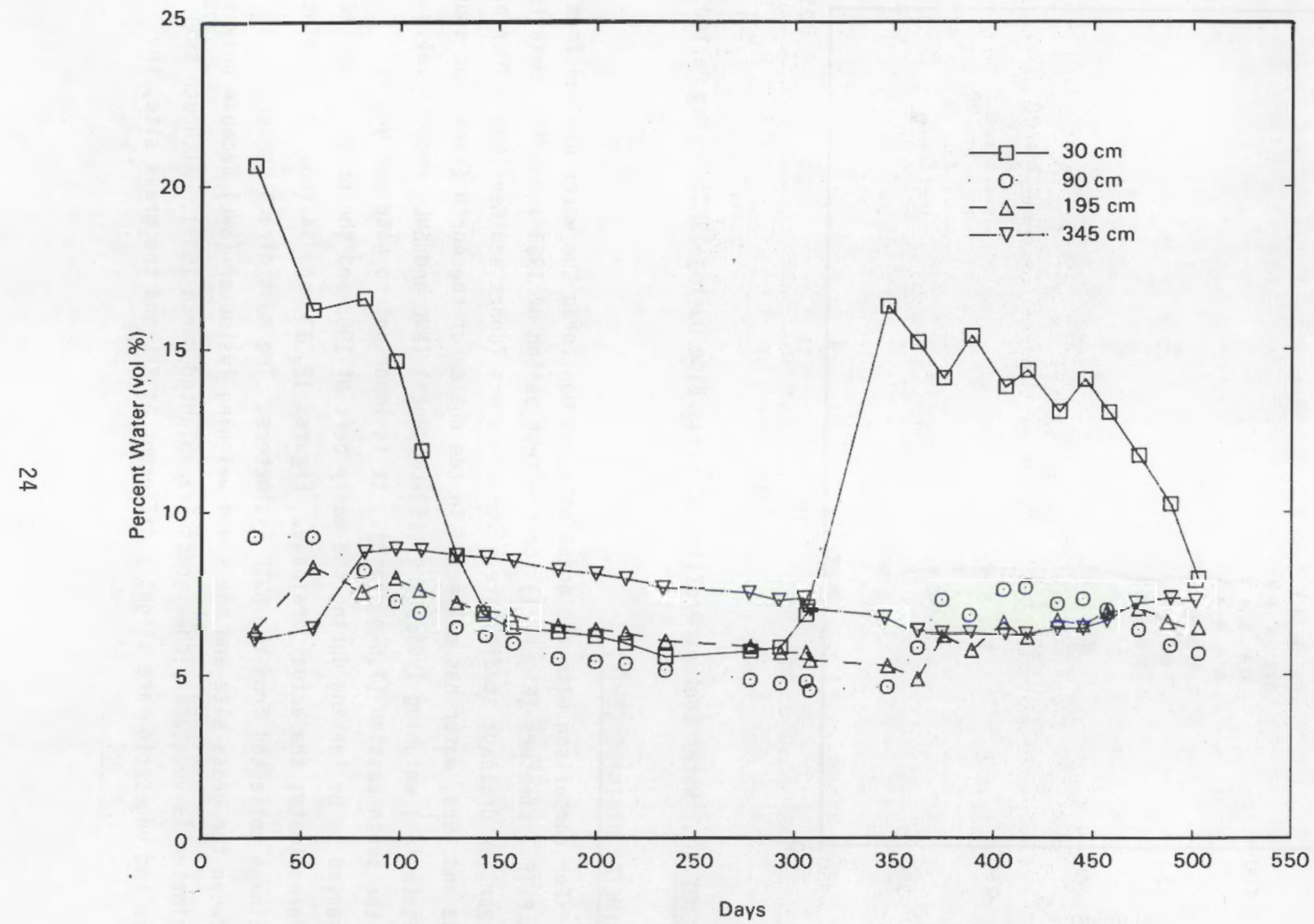

FIGURE 11. Measured Water Content Changes at Selected Depths at Grass Site 


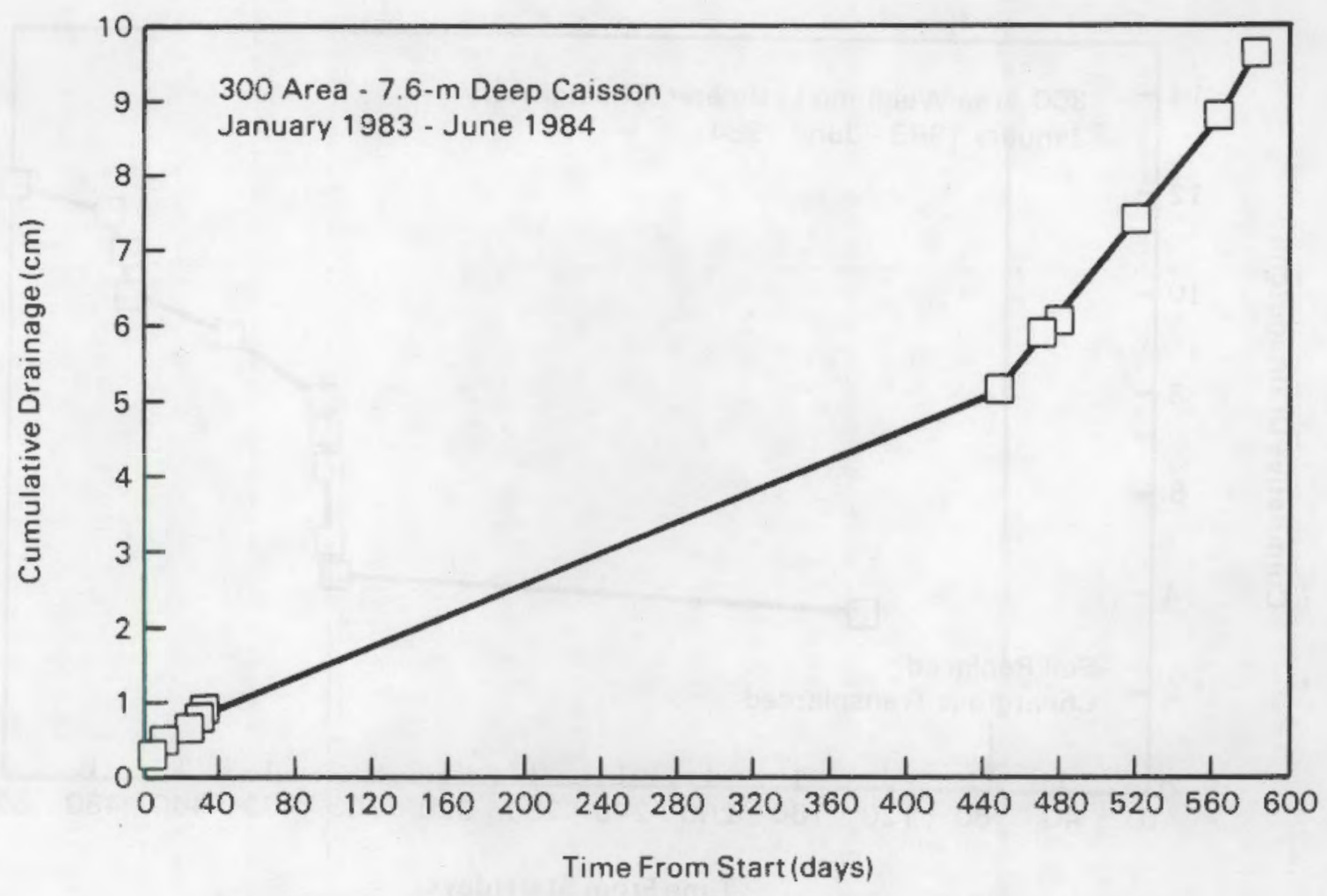

FIGURE 12. Drainage at the BWTF 7.6-m-Deep Caisson

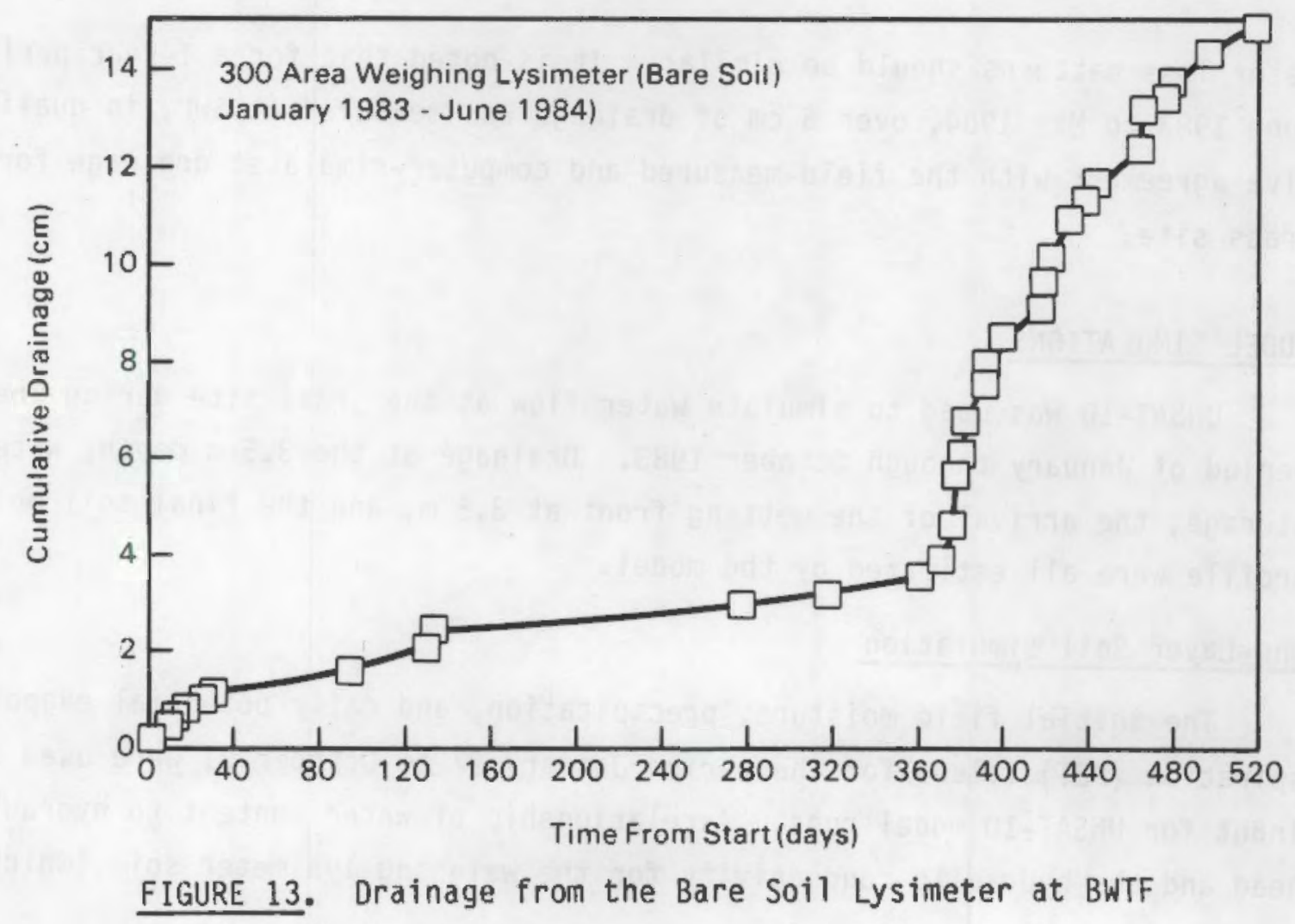




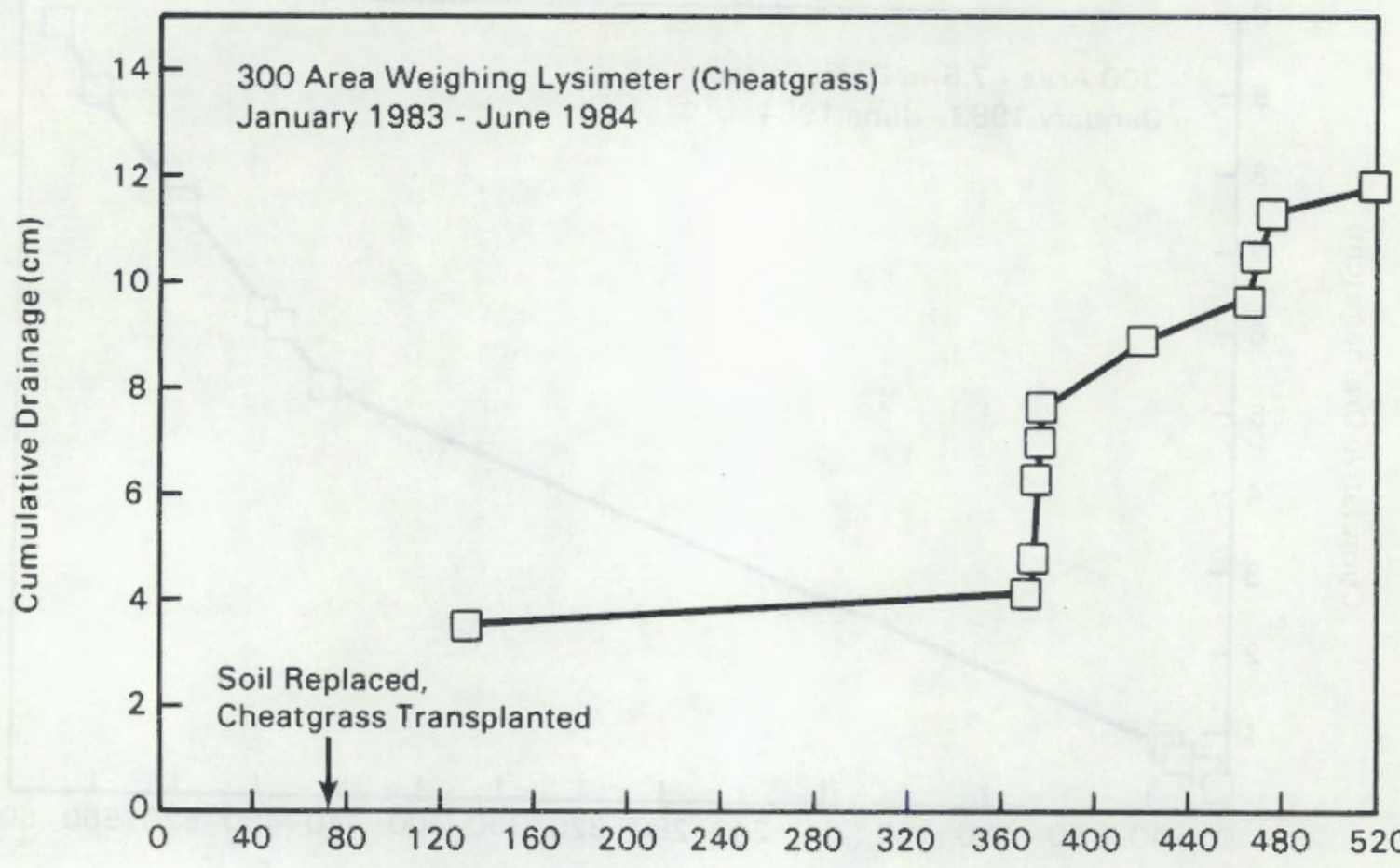

Time From Start (days)

FIGURE 14. Cumulative Drainage at South Weighing Lysimeter

water loss patterns should be similar. It is noted that for a 1-year period, June 1983 to May 1984, over $6 \mathrm{~cm}$ of drainage was measured at SWL, in qualitative agreement with the field-measured and computer-simulated drainage for the grass site.

MODEL SIMULATIONS

UNSAT-10 was used to simulate water flow at the grass site during the period of January through October 1983. Drainage at the $3.5-m$ depth, water storage, the arrival of the wetting front at $3.5 \mathrm{~m}$, and the final soil moisture profile were all estimated by the model.

One-Layer Soil Simulation

The initial field moisture, precipitation, and daily potential evapotranspiration (PET) values for the period January 27 to October 31 were used as input for UNSAT-1D model runs. A relationship of water content to hydraulic head and the hydraulic conductivity for the weighing lysimeter soil (which is 
similar to the soil at the 1 to $3.5-m$ depth at the grass site), was used as input to the model. A routine describing cheatgrass transpiration versus time, taken from published results at the Hanford site (Hinds 1975), was used to estimate transpiration. Root growth and distribution routines were similar to those described by Feddes et al. (1976).

Sensitivity of the model results to transpiration was investigated by varying the starting date for cheatgrass growth. Figure 15 shows the measured water storage curve presented earlier and two water storage curves obtained from UNSAT-1D using two different growing seasons for the simulated cheatgrass cover. For CHEAT120 the growing season begins at day 120 and continues for 70 days; CHEAT90 is identical, except growth begins on day 90 and continues for 70 days. The two curves coincide until day 90, at which point the initiation of transpiration increases the rate of water loss from the profile of the CHEAT90 curve. CHEAT120 also exhibits a rapid loss of water after transpiration begins on day 120. It is important to note the overlap of the CHEAT90 and CHEAT120 curves after day 178 caused by partial storage of a large summer rain $(0.9 \mathrm{~cm})$ in the CHEAT90 simulation, after transpiration has ceased. UNSAT-1D estimated approximately $5 \mathrm{~cm}$ of drainage in both runs at the $3.5 \mathrm{~m}$ depth, while a maximum flux of $8.6 \mathrm{~cm}$ occurred at $1.8 \mathrm{~m}$. Flux rates above $1.8 \mathrm{~m}$ were less than $8.6 \mathrm{~cm}$, indicating that water was redistributed upward in the model simulation.

The arrival of the wetting front at the 3.5-m depth is predicted 1 month later than actually occurs in the field. The simulated redistribution of water downward does not reach the 3.5-m depth until after April 30, and the water content behind the wetting front approaches $9 \%$. The field data presented earlier in Figure 5 indicate that the wetting front reaches the $3.5-m$ depth no later than March 23, and that the water content immediately following the wetting front is between $7 \%$ and $8 \%$.

The UNSAT-10 model simulation of $5 \mathrm{~cm}$ of drainage appears to agree with the field data for the test period, but adjustments are needed to obtain agreement on the final profile storage and water available for transpiration from the root zone. Differences between UNSAT-1D simulations and field data include the removal of water from the root zone and storage of water in the lower soil profile. 


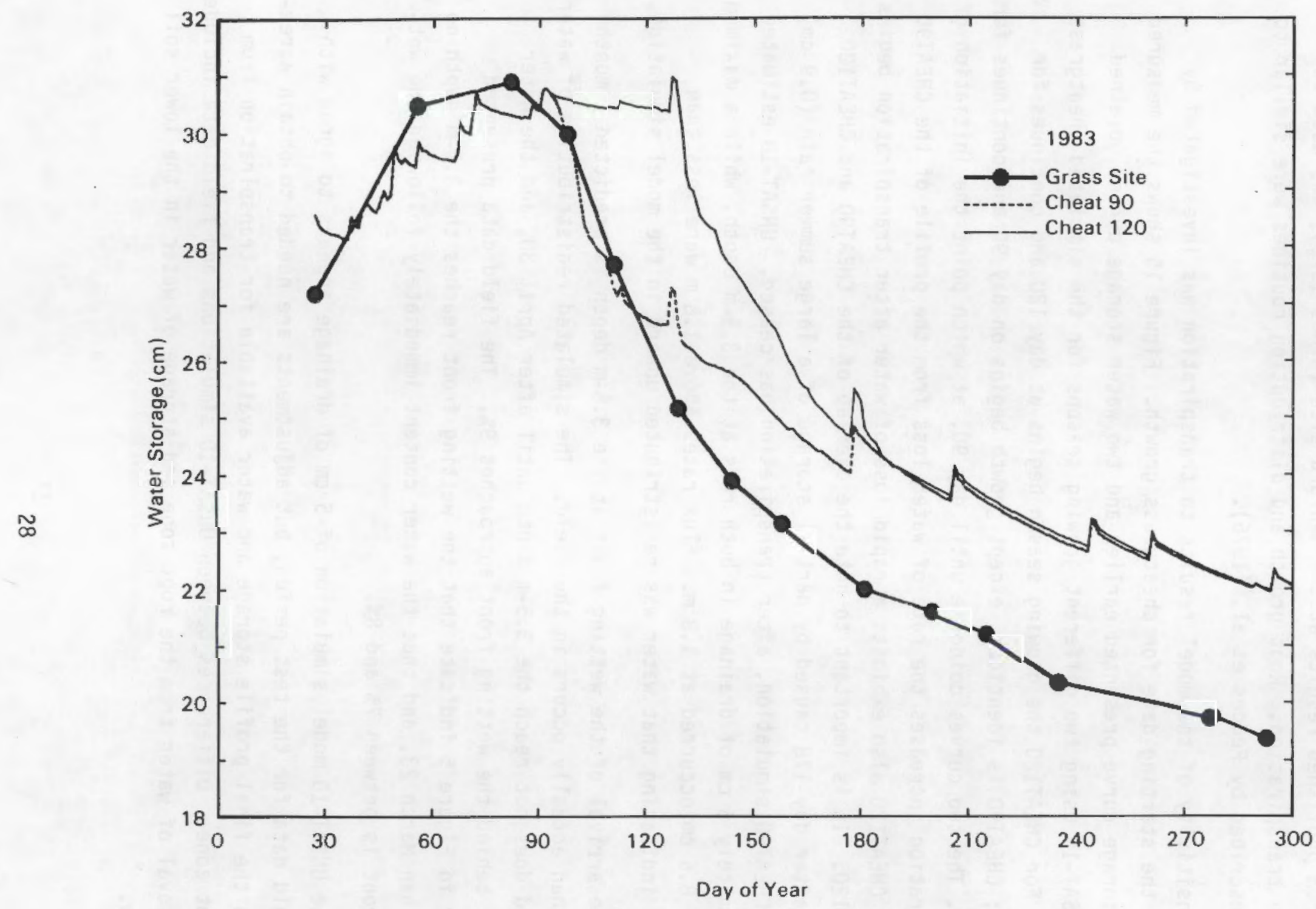

FIGURE 15. Measured and Modeled Water Storage Changes for One Layer of Soil at Grass Site 
Two-Layer Soil Simulation

UNSAT-1D was used to simulate water flow at the grass site during the period of January 1983 to June 1984. Drainage at $3.5 \mathrm{~m}$, water storage, the arrival of the wetting front at $3.5 \mathrm{~m}$, and the final soil moisture profile were estimated by the model. The same starting soil moisture content and meteorological information used in the single-layer simulation was used in the twolayer simulations. The meterological information was extended through June 1984. The soil hydraulic parameters were changed to match those determined during the field drainage test discussed earlier. The same transpiration algorithm using cheatgrass was used, but the growing season was lengthened starting on day 5 and ending on day 152. During this simulation, the drainage from the two-layer model during 1983 was $3.5 \mathrm{~cm}$ and $0.4 \mathrm{~cm}$ during the first 6 months of 1984. The field-measured moisture profile and the UNSAT-1D-predicted moisture profiles for December 28, 1983 and June 26, 1984 are presented in Figure 16. The UNSAT-1D model simulations tend to slightly overpredict the moisture in December 28 and slightly underpredict the moisture on June 26 , but the agreement is quite good showing the general trend of moisture movement, with the major changes occurring near the soil surface (within the top $1 \mathrm{~m}$ of soil). Figure 17 shows the total water stored through time from January 1983 to June 1984. Figure 17 also shows the actual field-measured, total stored water from the grass site. The storage change curves are cyclic as expected, and simulated and field values match well in magnitude, but the simulated results appear to lead the field values, particularly for the 1984 data. An overestimation of evapotranspiration as discussed below may be responsible. Figure 18 shows the soil water contents at $30,90,195$, and $345 \mathrm{~cm}$ through time. These data can be compared with the field data contained in Figure 11, which shows the data of $30,90,195$, and $345 \mathrm{~cm}$ for the grass site. The field data have broader and more delayed peaks than those predicted by the model. Also the field data for $345 \mathrm{~cm}$ showed increases during both springs as compared to the model, which only showed an increase during the spring of 1983. These data suggest that the model is underestimating actual field drainage. 


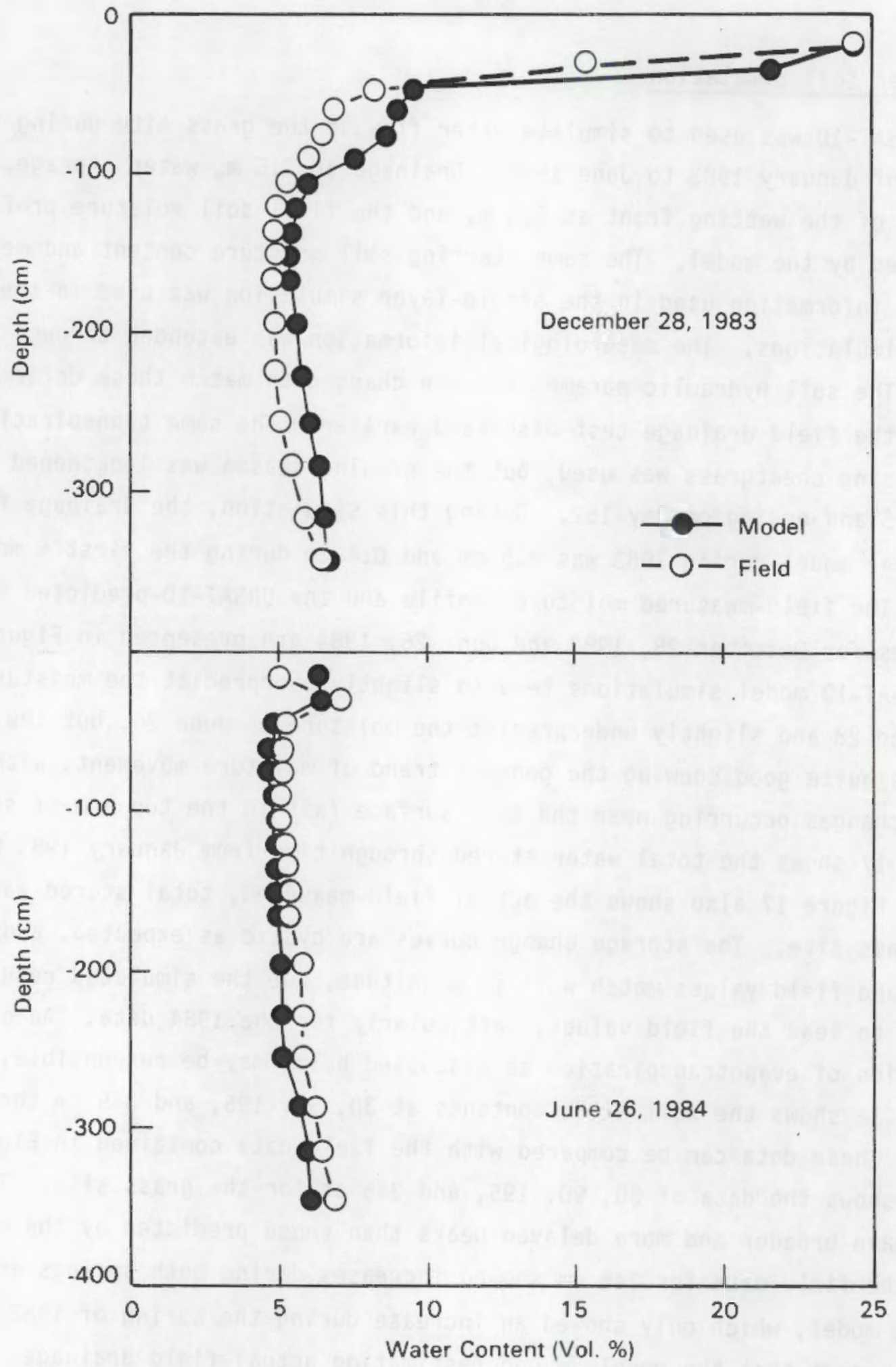

FIGURE 16. Water Content Profiles at Grass Site. Measured using neutron probe water content profiles on December 28, 1983, and June 26, 1984, and compared to UNSAT-10 model simulations 


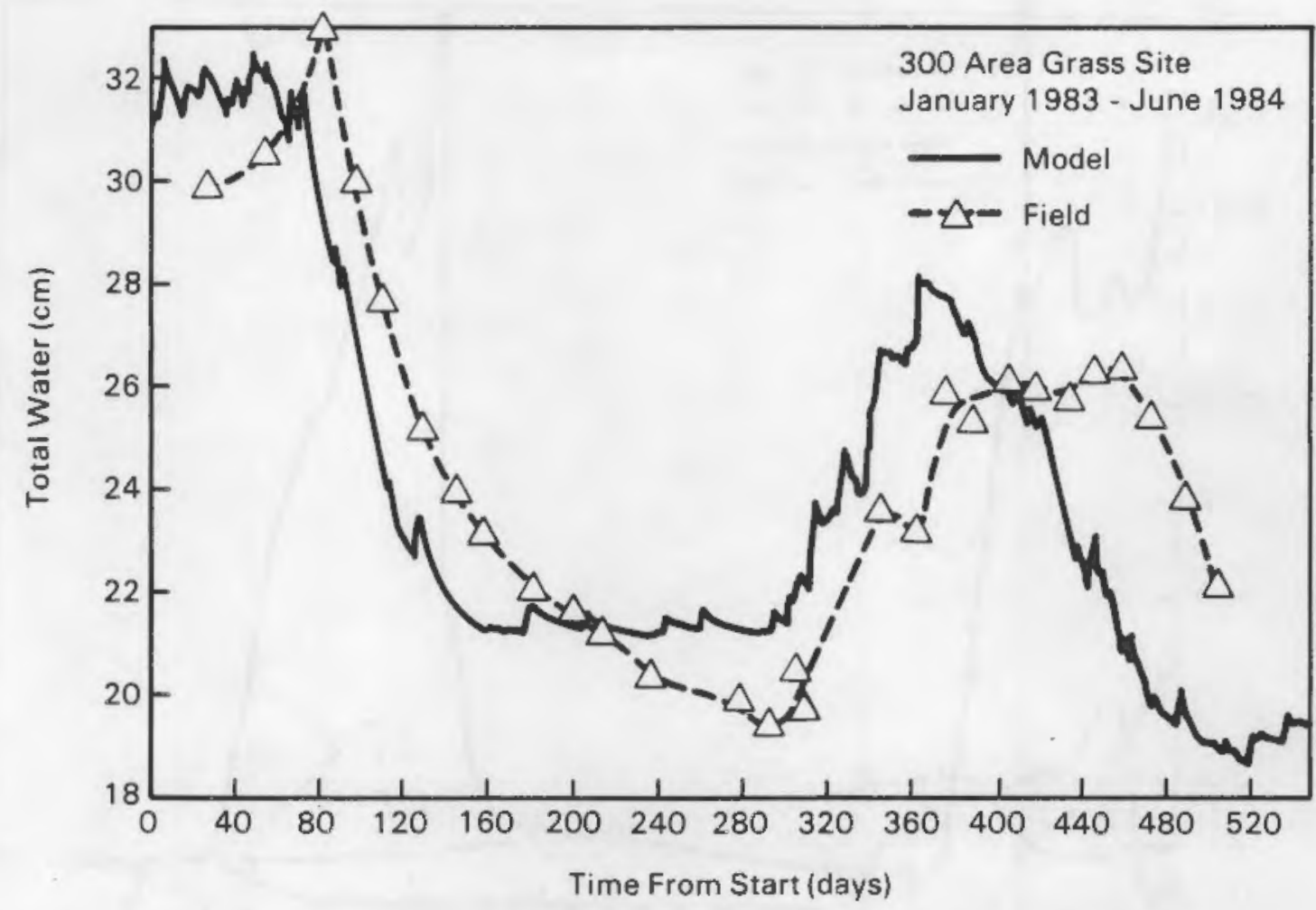

FIGURE 17. Calculated Water Content Changes at Grass Site Since January 1, 1983

\section{EVAPOTRANSPIRATION COMPARISONS}

The evapotranspiration rates predicted using UNSAT-10 were compared with evapotranspiration rates measured from the weighing lysimeter to qualitatively check the validity of the cheatgrass alogrithms used. The monthly totals for evapotranspiration are presented in Table 1. The model predicts larger values of evapotranspiration than the SWL for January, February, and March, and a smaller value during April. Correcting the evapotranspiration amounts would increase the drainage estimated by the model for the 1984 time period (January to May). Because plant cover, soil type, and energy balance differed somewhat between the grass site and the SWL, we did not attempt to calibrate the field model to the SWL evapotranspiration data, but merely used SWL data to estimate when the transpiration process was active during the modeling time period. 


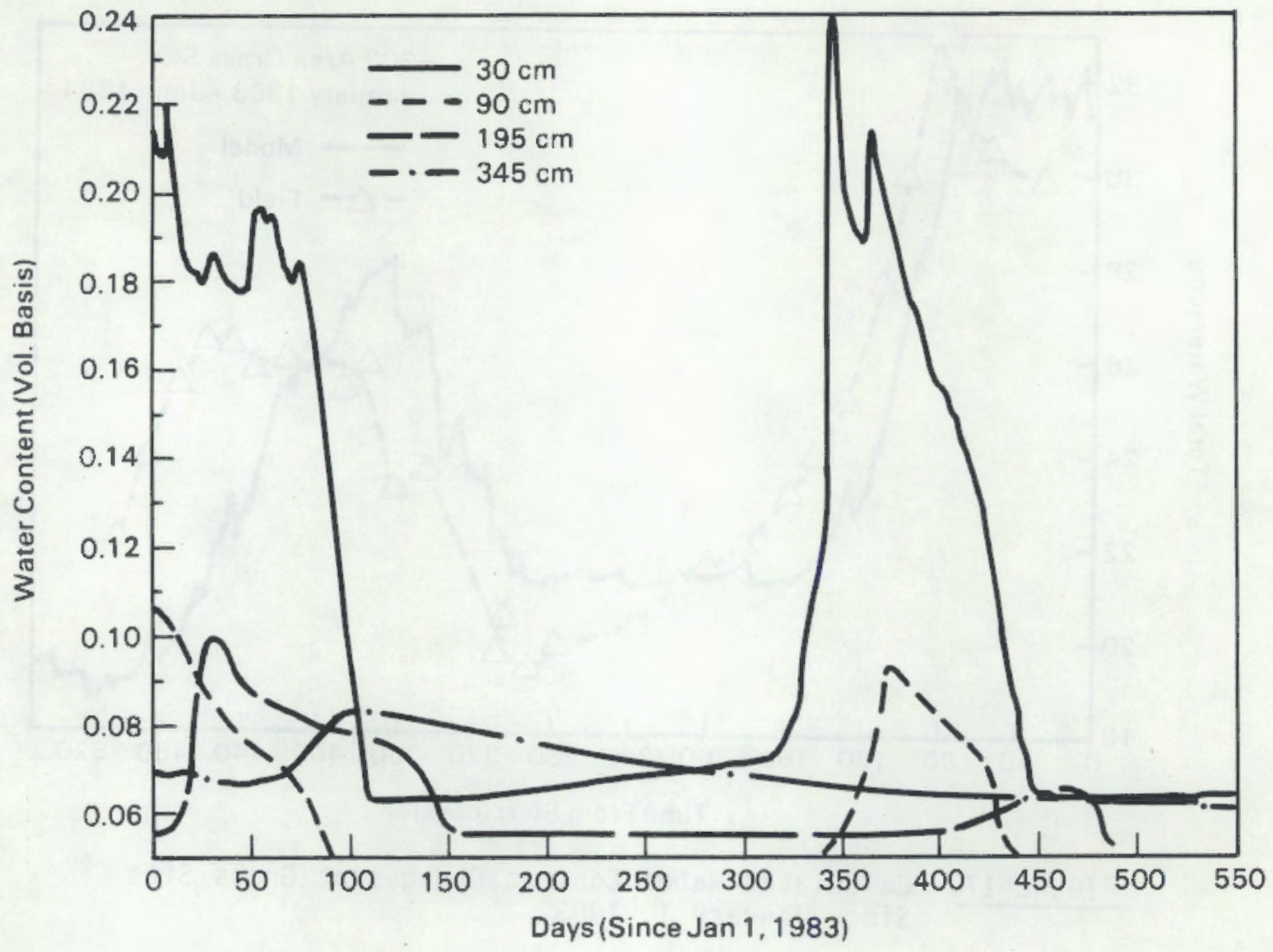

FIGURE 18. Model Simulation of Water Content Changes with Depth at Grass Site Using Two-Layer Model

TABLE 1. Comparison of Predicted and Measured Evapotranspiration Rates (monthly) for 1984

Measured (SWL)

\begin{tabular}{|c|c|c|c|}
\hline January & February & March & April \\
\hline 1.7 & 2.3 & 4.1 & 5.2 \\
\hline 2.3 & 3.5 & 5.6 & 3.1 \\
\hline
\end{tabular}

Predicted (UNSAT-1D) 


\section{DISCUSSION}

The field measurements and model simulations for 1983 and 1984 are in general agreement with data from Cline, Uresk and Rickard (1977), who observed that a cheatgrass site used less water than a deeper-rooted sagebrushbunchgrass site, and that during a wet season at the Hanford site, water accumulated below the cheatgrass root zone. The combined effects of rainfall distribution patterns, plant cover type, and soil hydraulic properties on the amount of annual drainage occurring at an arid site cannot be overemphasized. The need for detailed analysis to evaluate these effects is apparent. A recent evaluation of unsaturated flow models (Oster 1982) indicates that several flow codes may be equivalent to UNSAT-1D in evaluating the water balance under arid conditions. Among these are UNSAT20, TRUST, and VS20. However, these are twodimensional codes that are considerably more expensive to run and require greater input detail. We have evaluated the CREAMS (Knisel 198D) and HELP (Schroeder et al. 1984) codes for water balance measurements. The HELP code is a modification of the CREAMS code for use in designing cover systems at hazardous waste sites. The HELP code was found to be totally inadequate for predicting yearly drainage through a soil cover at an arid site (Thompson and Tyler 1984). The HELP model does not allow for upward migration and treats water redistribution in the soil in a superficial way. It is apparent from a review of CREAMS and HELP that site-specific calibrations will be required to use these codes to estimate drainage/recharge at arid sites.

Model simulations using UNSAT-10 were useful in showing the delicate balance between mechanisms that control drainage. Although the agreement between measured and simulated storage and drainage could be improved, the simulations suggest a control mechanism for reducing drainage of an arid waste site. The layered soil simulations showed a greater retention of water than the singlelayer sandy soil, hence, less drainage occurred. An engineered cover could be designed to reduce or eliminate drainage at an arid site. This would involve using a fine-textured soil as an earthern cover with hydraulic properties such that the water retention and soil hydraulic conductivity would keep the water in the root zone during periods of low evapotranspiration. Then at later times, the water would be removed by transpiration processes. 
Often, in the absence of detailed hydrologic analysis, generalizations are made suggesting that when annual potential evapotranspiration exceeds precipitation (often by factors of five or more at arid sites), no drainage occurs. Dur data clearly indicate that drainage can occur at an arid site under circumstances where shallow-rooted plants grow on coarse sands and when above-average rainfall occurs during periods of low potential evapotranspiration. 
CONCLUSIONS

Significant quantities of water were found to move below the root zone of a shallow-rooted grass-covered area during wet years at the Hanford site. The unsaturated water flow model, UNSAT-1D, was reasonably successful in simulating the transient behavior of the water balance at this site. The effects of layered soils on water balance were demonstrated using the model. Models used to evaluate water balance in arid regions should not rely on annual averages and assume that all precipitation is removed by evapotranspiration. The potential for drainage at arid sites exists under conditions where shallow rooted plants grow on coarse textured soils. This condition was observed at our study site at Hanford.

Neutron probe data collected on a cheatgrass community at the Hanford site during a wet year (28 $\mathrm{cm}$ of precipitation) indicated that over $5 \mathrm{~cm}$ of water drained below the 3.5-m depth. The unsaturated water flow model, UNSAT-1D, predicted water drainage of approximately $5 \mathrm{~cm}$ (single layer, 10 months) and $3.5 \mathrm{~cm}$ (two layers, 12 months) for the same time period. Additional field measurements of hydraulic conductivity will likely improve the drainage estimate made by UNSAT-1D. Additional information describing cheatgrass growth and water use at the grass site could improve model predictions of sink terms and subsequent calculations of water storage within the rooting zone.

In arid areas where the major part of the annual precipitation occurs during months with low average potential evapotranspiration and where soils are vegetated but are coarse textured and well drained, significant drainage can occur. Water balance control strategies for arid-zone shallow-land burial sites like the Hanford site, where climatic and soil factors combine to optimize drainage, may require use of fine-textured-soil covers over the waste to reduce drainage below the root zone. 


\section{REFERENCES}

Al-khafaf, S., P. J. Wierenga and B. C. Williams. 1977. "A Flotation Method for Determining Root Mass in Soi1." Agronomy Journal 69(6):1025-1026.

Bond, F. W., M. D. Freshley and G. W. Gee. 1982. Unsaturated Flow Modeling of a Retorted 0il Shale Pile. PNL-4284, Pacific Northwest Laboratory, Richiand, Washington.

Brownel1, L. E., J. G. Backer, R. E. Isaacson and D. J. Brown. 1975. Soil Moisture Transport in Arid Site Vadose Zones. ARH-ST-123, National Technical Information Service, Springfield, Virginia.

Cline, J. F., D. W. Uresk and W. H. Rickard. 1977. "Comparison of Soil Water Used by a Sagebrush-Bunchgrass and a Cheatgrass Community." Journal of Range Management 30(3):199-201.

Daubenmire, R. 1959. "A Canopy-Coverage Method of Vegetation Analysis." Northwest Science 3:43-64.

Davidson, J. M., L. R. Stone, D. R. Nielsen and M. E. Larue. 1969. "Field Measurement and Use of Soil-Water Properties," Water Resources Research $5(6): 1312-1321$.

Feddes, R. A., P. Kowalik, K. Kolinska-Malinka and J. Zaradny. 1976. "Simulation of Field Water Uptake by Plants Using a Soil Water Dependent Root Extraction Function." J. Hydrology 31:13-26.

Gupta, S. K., K. K. Tanji, D. R. Nielson, J. W. Biggar, C. S. Simmons and J. L. Macintyre. 1978. Field Simulation of Soil-Water Movement with Water Extraction. Water Science and Engineering Paper No. 4013, Department of Land, Air, and Water Resources, University of California, Davis, California.

Hanks, R. J., and G. L. Ashcroft, 1980. Applied Soil Physics. SpringerVerlag, New York.

Hinds, W. T. 1975. "Energy and Carbon Balances in Cheatgrass: An Essay in Autoecology." Ecological Monograph 45:367-388.

Hille1, D. 1977. Computer Simulation of Soil-Water Dynamics. Int. Dev. Res. Centre, Ottawa, Canada.

Hillel, D. 1982. Introduction to Soil Physics. Academic Press, New York.

Hillel, D., V. D. Krentos and Y. Stylianou. 1972. "Procedure and Test of an Internal Drainage Method for Measuring Soil Hydraulic Characteristics In Situ." SoiT Sci. 114:395-400. 
Jones, T. L. 1978. Sediment Moisture Relationships: Lysimeter Project 1977 Water Year. RHO-ST-15, National Technical Information Service, Springfield, Virginia.

Jones, T. L., and G. W. Gee. 1984. Assessment of Unsaturated Zone Transport for Shallow Land Burial of Radioactive Waste: Summary Report of Technotogy Needs, Model Verification and Measurement Efforts (FY78-FY83). PNL-4747, Pacific Northwest Laboratory, Richland, Washington.

Jones, T. L., G. S. Campbell and G. W. Gee. 1984. Water Balance at An Arid Site: A Model Validation Study of Bare Soil Evaporation. PNL-4896, Pacific Northwest Laboratory, Richland, Washington.

Klute, A., and D. F. Heermann. 1978. Water Movement in Uranium Mill Tailings Profiles. Tech. Note $0 R P / L V-78-8$, Office of Radiation Programs, U.S. Environmental Protection Agency, Las Vegas, Nevada.

Knisel, W. G., Jr. (ed). 1980. CREAMS: A Field Scale Model for Chemicals, Runoff and Erosion from Agricultural Management Systems. U.S. Department of Agriculture, Conservation Research Report No. 26, Washington, D.C.

Marshall, T. J., and J. W. Holmes. 1979. Soil Physics. Cambridge Univ. Press, London, England.

Mckeon, T. J., S. W. Tyler, D. W. Mayer and A. E. Reisenauer, 1983. TRUST-II Utility Package: Partially Saturated Soil Characterization, Grid Generation, and Advective Transport AnaTysis. NUREG/CR-3443 (PNL-4805), U.S. NuCTear Regulatory Commission, Washington, D.C.

Mercer, J. W., P. S. C. Rao and I. W. Marine (eds). 1983. Role of the Unsaturated Zone in Radioactive and Hazardous Waste 0isposal, Ann Arbor Publishing, Ann Arbor, Michigan.

Molz, F. J., J. M. Oavidson and E. W. Tollner. 1979. "Unsaturated-Zone Water." Papers in Hydrology, Seventeenth General Assembly International Union of Geodesy and Geophysics, Amer. Geophysical Union 17:1221-1239.

Nimah, M. N., and R. J. Hanks. 1973. "Model for Estimating Soil, Water, Piant, and Atmospheric Interactions: 1. Description and Sensitivity." Soil Sci. Soc. Am. Proc. 37:522-527.

Oster, C. A. 1982. Review of Ground-Water Flow and Transport Models in the Unsaturated Zone. NUREG/CR-2917 (PNL-4427) U.S. NuClear Regulatory Comission, Washington, D.C.

Penman, H. L. 1948. "Natural Evaporation from 0pen Water, Bare Soil, and Grass." Proc. Roy. Soc. London A193:120-145. 
Richards, L. A. 1965. "Physical Condition of Water in Soil." In Methods of Soil Analysis, pp. 128-152, Monograph 9. Amer. Soc. Agron., Madison, Wisconsin.

Schroeder, P. R., S. M. Morgan, T. M. Walski and A. C. Gibson, 1984. The Hydrologic Evaluation of Landfill Performance (HELP) Model Vol. 1, User's Guide for Version 1. EPA/530-SW-84-009, U.S. Environmental Protection Agency, Cincinnati, ohio.

Simmons, C. S., and G. W. Gee. 1981. Simulation of Water Flow and Retention in Earthen Cover Materials Overlying Uranium Mill Tailings. PNL-3877 (UMT/0203), Pacific Northwest Laboratory, Richland, Washington.

Thompson, F. L. and S. W. Tyler. 1984. Comparison of Two Groundwater Flow Models (UNSATID and HELP) and Their AppTication to Covered FTy Ash Disposal Sites. EPRI Document Series, August 1984, Electric Power Research Institute, Palo Alto, California.

Wallace, R. W. 1978. A Comparison of Evapotranspiration Estimates for Hanford Climatological Data. PNL-2698, Pacific Northwest Laboratory, Richland, Washington.

Winograd, 1. J. 1981. "Radioactive Waste Disposal in Thick Unsaturated Zones." Sci. 212:1457-1464. 
APPENDIX A

PNL PUBLICATIONS RELATED TO TRANSPORT ASSESSMENT - ARID 


\section{APPENDIX A}

\section{PNL PUBLICATIONS RELATED TO TRANSPORT ASSESSMENT - ARID}

Phillips, S. J., A. C. Campbel1, M. D. Campbell, G. W. Gee, H. H. Hoober and K. 0. Schwarzmiller. November 1979. A Field Test Facility for Monitoring Water/Radionuclide Transport Through Partially Saturated Geologic Media: Design, Construction, and Preliminary Description. PNL-3226, Pacific Northwest Laboratory, Richland, Washington.

Jones, T. L., W. A. Jordan and G. W. Gee. August 1979. A Test of the BreslerRusso-Miller Method for Unsaturated Conductivities. RHO-SA-125, Rockwell Hanford Operations, Richland, Washington.

Gee, G. W., and A. C. Campbell. March 1980. Monitoring and Physical Characterization of Unsaturated Zone Transport -- Laboratory Analysis. PNL-3304, Pacific Northwest Laboratory, Richland, Washington.

Gibbs, A. G. April 1981. Analytical Solutions of Moisture Flow Equations and Their Numerical Evaluation. PNL-3680, Pacific Northwest Laboratory, Richland, Washington.

Gee, G. W., A. C. Campbell, P. J. Wi erenga and T. L. Jones. June 1981. Unsaturated Moisture and Radionuclide Transport: Laboratory Analysis and Modeling. PNL-3616, Pacific Northwest Laboratory, Richland, Washington.

Campbell, G. S., and G. W. Gee. 1984. "Miscellaneous Methods for Measuring Water Potential." Submitted to ASA Monograph Methods of Soil Analys is in press). Also PNL-SA-9730, Pacific Northwest Laboratory, Richland, Washington.

Cass, A., G. S. Campbell and T. L. Jones. October 1981. Hydraulic and Thermal Properties of Soil Samples from the Buried Waste Test Facility. PNL-4015, Pacific Northwest Laboratory, Richland, Washington.

Jones, T. L, G. W. Gee, R. R. Kirkham and D. D. Gibson. August 1981. The Measurement of Water Potential in Low-Level Waste Management. PNL-4388, Pacific Northwest Laboratory, Richland, Washington.

Cass, A., G. S. Campbell and T. L. Jones. September 1983. "The Enhancement of Thermal Water Vapor Diffusion in Soils." Soil Science Society of America Journal. 48:25-32.

Jones, T. L., and G. W. Gee. October 1983. Assessment of Unsaturated Zone Transport. PNL-4747, Pacific Northwest Laboratory, Richland, Washington. 
Jones, T. L., G. W. Gee, J. L. Swanson and R. R. Kirkham. 1983. A field and laboraory evaluation of the mobility of cobalt-60/EDTA in an arid environment. R. G. Post (ed.), Waste Management '83, Vol. 2, p. 331-333. University of Arizona Press, Tucson, Arizona.

Jones, T. L., G. S. Campbell and G. W. Gee. 1984. Water Balance at an Arid Site: A Model Validation Study of Bore Soil Evaporation. PNL-4896. Pacific Northwest Laboratory, Richland, Washington.

Kirkham, R. R., G. W. Gee and T. L. Jones. 1984. "Weighing Lysimeters for Water Balance Measurements at Remote Sites." Soil Sci. Soc. Am. J. 48:1203-1205. 


\section{DISTRIBUTION}

No. of

Copies

OFFSITE

D. E. Large, National Program

Manager ORO Radioactive Waste

Management Program

Oak Ridge Operations Branch

U.S. Department of Energy

P.0. Box E

Oak Ridge, TN 37830

L. J. Mezga, Program Manager

Low-Level Waste Management Program

Dak Ridge National Laboratory

P.0. Box $X$

Oak Ridge, TN 37830

M. J. Barainca, Program Manager

Low-Level Waste Management Program

Idaho Operations office

U.S. Department of Energy

550 Second Street

Idaho Falls, ID 83401

R. Bol and

Waste Management Project

office

Nevada Operations Office

U.S. Department of Energy

P.0. Box 14100

Las Vegas, NV 89114

T. C. Chee

R\&O and Byproducts Division

DP-123 (GTN)

U.S. Department of Energy

Washington, DC 20545

B. W. Church, Di rector

Health Physics Division

Nevada Operations Office

U.S. Department of Energy

P.0. Box 14100

Las Vegas, NV 89114
No. of

Copies

J. A. Coleman, Director

Division of Storage and

Treatment Projects

NE-25 (GTN)

U.S. Department of Energy

Washington, DC 20545

J. E. Dieckhoner, Acting

Director

Operations and Traffic Division

DP-122 (GTN)

U.S. Department of Energy

Washington, DC 20545

C. P. Gertz, Chief

Radioactive Waste Technology

Branch

Idaho Operations office

U.S. Department of Energy

550 Second Street

Idaho Falls, ID 83401

F. Gorup, Program Manager

Nuclear Waste Management Group

Chicago Operations office

U.S. Department of Energy

9800 South Cass Avenue

Argonne, IL 60439

J. J. Jicha, Director

R\&D and Byproducts Division

DP-123 (GTN)

U.S. Department of Energy

Washington, DC 20545

E. A. Jordan

Low-Level Waste Program

Manager

Division of Storage and

Treatment Projects

NE-25 (GTN)

U.S. Department of Energy

Washington, DC 20545 
No. of

Copies

L. Lanni, Chief

Waste Management Nuclear

Magnetic Fusion Division

San Francisco Operations office

U.S. Department of Energy

1333 Broadway

Oakland, CA 94612

B. Lawless

Process and Weapons Division

Savannah River Operations office

U.S. Department of Energy

P.0. Box A

Aiken, SC 29801

J. M. McGough, Jr., Director

Waste Management and Transpor-

tation Development Division

Albuquerque Operations office

U.S. Department of Energy

P.0. Box 5400

Albuquerque, NM 87115

D. M. Lund

Waste Management and Transportation Development Division

Albuquerque Operations office

U.S. Department of Energy

P.0. Box 5400

Albuquerque, NM 87115

S. Mann, Senior Program Manager

Technical Management Division

Chicago Dperations office

U.S. Department of Energy

9800 South Cass Avenue

Argonne, IL 60439

C. L. Mathews, Chief

Fission Reactor Branch

Oak Ridge Operations Branch

U.S. Department of Energy

P.0. Box E

oak Ridge, TN 37830
No. of

Copies

D. B. Leclaire, Director

office of Defense Waste

and Byproducts Management

DP-12 (GTN)

U.S. Department of Energy

Washington, DC 20545

H. Saucier

Process and Weapons Division

Savannah River Operations office

U.S. Department of Energy

P.0. Box A

Aiken, SC 29801

3. B. Whitsett, Chief

Production and Waste

Management Branch

Idaho Operations office

U.S. Department of Energy

55D Second Street

Idaho Falls, ID 83401

27 DOE Technical Information Center

S. M. Brown, P.E.

Anderson-Nichols

2666 E. Bayshore Road

Palo Alto, CA 94303

C. S. Abrams, Manager of

Radiological Engineering

Argonne National Laboratory West

P.0. Box 2528

Idaho Fal1s, ID 83401

J. Howard Kittel, Manager

Office of Waste Management Programs

Argonne National Laboratory

97D0 S. Cass Avenue, B1dg. 205

Argonne, IL 60439

Technical Library

Argonne National Laboratory

Argonne, IL 6D439 
No. of

Copies

Beveriy Rawles

Battelle Memorial institute

Office of Nuclear Waste Isolation

505 King Avenue

Columbus, $\mathrm{OH} 43201$

Peter Colombo, Group Leader

Nuclear Waste Research

Brookhaven National Laboratory

Building 701

Upton, NY 11973

R. H. Beers, Manager

Waste Management Programs

Division

EG\&G Idaho, Inc.

P.0. Box 1625

Idaho Falls, ID 83415

E. A. Jennrich

Low-Level Management

Program

EG\&G Idaho, Inc.

P.0. Box 1625

Idaho Falls, Idaho 83415

Environmental Protection Agency

Technology Assessment Division

Office of Radiation Programs

Washington, D.C. 20460

Jack G. Couch

Fermi National Accelerator Laboratory

P.0. Box 500

Batavia, IL 60510

R. E. Anderson

Goodyear Atomic

P.0. Box 628

Piketon, OH 45661

Technical Library

Idaho National Engineering Laboratory

Idaho Falls, Idaho 83401
No. of

Copies

Dr. T. Harvey

Mai i Stop L-262

Lawrence Livermore National Laboratory

P.0. Box 808

Livermore, CA 94550

Donald T. Oakley

Program Manager for Waste

Management

Los Alamos National Laboratory

P.0. Box 1663

Los Alamos, NM 87545

J. G. Steger

Los Alamos Scientific Laboratory

Los Alamos, NM 87545

Technical Library

Los Alamos National Laboratory

Los Alamos, New Mexico 87545

J. McMenamin

Mason and Hanger - Silas

Mason Co.

Pantext Plant

P.0. Box 30020

Amarillo, TX 79177

R. R. Jaeger, Manager

Nuclear Waste Technology

Monsanto Research Corporation

P.0. Box 32

Miamisburg, OH 45342

National Academy of Sciences

National Research Council

2101 Constitution Avenue

Washington, DC 20418

J. S. Baldwin

Low-Level Waste Management

Program

Dak Ridge National Laboratory

P.0. Box $X$

Oak Ridge, TN 37830 
No. of

Copies

T. H. Row, Director

Nuclear Waste Programs

Oak Ridge National Laboratory

P.O. Box $X$

Oak Ridge, TN 37830

Technical Library

Oak Ridge National Laboratory

0ak Ridge, Tennessee 37830

E. W. Kenda11

Waste Management Project

Manager

REECO

P. D. Box 642

Mercury, NV 89023

J. J. Blakeslee, Program Manager

Nuclear Waste Processing

Rockwell International

P.0. Box 464

Golden, CO 80401

C. E. Wickland

Manager, Waste Operations

Rockwell International

Rocky Flats Plant

P.0. Box 464

Golden, C0 80401

E. L. Albenesius

Savannah River Laboratory

P.0. Box A

Aiken, SC 29801

Technical Library

Savannah River National

Laboratory

Aiken, SC 29081

E. M. Romney

University of California

at Los Angeles

Westwood, CA 96137
No. of

Copies

\author{
W. A. Jury \\ Department of Soils \\ University of California \\ Riverside \\ Riverside, CA 92502 \\ J. H. Cary \\ U.S. Department of Agriculture \\ Snake River Conservation \\ Research Center \\ Route 1, Box 186 \\ Kimberly, ID 83341 \\ Jack Fischer \\ Low-Level Radioactive Waste \\ Program \\ U.S. Geological Survey \\ Water Resources Division \\ 12201 Sunrise Valley Drive \\ Reston, VA 22092 \\ I. J. Winograd \\ Geologic Survey \\ Reston, VA 22092 \\ E. P. Weeks \\ U.S. Geological Survey \\ Federal Center Mail Stop 413 \\ Denver, CO 80225 \\ F. J. Arsenault \\ Division of Health, Siting \\ and Waste Management Research \\ U. S. Nuclear Regulatory \\ Commission \\ Washington, DC 20555 \\ E. Conti \\ Division of Health, Siting \\ and Waste Management Research \\ U.S. Nuclear Regulatory \\ Commission \\ Washington, DC 20555
}


No. of

Copies

R. C. DeYoung

Division of Site Safety and Environmental Analysis

U.S. Nuclear Regulatory Comprission

Washington, DC 20555

E. O'Donnel?

Earth Sciences Branch

Division of Health, Siting and Waste Management Research

U.S. Nuclear Regulatory Commission

Washington, DC 20555

F. Swanberg

Division of Health, Siting and Waste Management Research

U.S. Nuclear Regulatory Commission

Washington, DC 20555

G. S. Campbell

Washington State University

Pullman, WA 99164

M. W. Boback, Director

Health and Safety Division

P.0. Box 39158

Cincinnati, $\mathrm{OH} 45239$

Jonathan Herrmann

Office of Solid Waste

U.S. Environmental Protection Agency

Municipal Environmental Research Laboratory

Cincinnati, OH 45268

ONSITE

Hanford Engineering Development Laboratory

R. E. Lerch
No. of

Copies

Richland Operations office

M. Dayani

G. Orten

H. E. Ransom

J. D. White

6

Rockwell Hanford Operations

J. F. Albaugh

R. E. Isaacson

W. A. Jordan

S. L. Phillips

J. F. Relyea

R. C. Routson

W. J. Waugh

United Nuclear Industries

P. Ortiz

Pacific Northwest Laboratory

D. W. Dragnich

J. L. Downs-Berg

M. J. Fayer

G. W. Gee (10)

M. J. Graham

P. C. Hays

P. R. Heller

T. L. Jones

C. T. Kincaid

R. R. Kirkham (5)

L. T. Lakey

I. C. Nelson

A. E. Reisenauer

R. J. Serne

C. S. Simmons

J. A. St ott 1 emy re

L. L. Wendel 1

Technical Information (5)

Publishing Coordination (2)

Geoscience Research \&

Engineering Department

Library (8) 


.

8

$*$

1.

1

$\checkmark$

4 